\title{
Neuronal nicotinic acetylcholine receptors: common molecular substrates of nicotine and alcohol dependence
}

\section{Linzy M. Hendrickson, Melissa J. Guildford and Andrew R. Tapper*}

Department of Psychiatry, Brudnick Neuropsychiatric Research Institute, University of Massachusetts Medical School, Worcester, MA, USA

\section{Edited by:}

Nicholas W. Gilpin, Louisiana State University Health Sciences Center New Orleans, USA

\section{Reviewed by:}

Shaolin Wang, University of Virginia, USA

Darlene H. Brunzell, Virginia Commonwealth University, USA Shafiqur Rahman, South Dakota State University, USA

\section{*Correspondence}

Andrew R. Tapper, Department of Psychiatry, Brudnick Neuropsychiatric Research Institute, University of Massachusetts Medical School, 303 Belmont Street, Worcester, MA 01604, USA. e-mail: andrew.tapper@ umassmed.edu
Alcohol and nicotine are often co-abused. As many as $80-95 \%$ of alcoholics are also smokers, suggesting that ethanol and nicotine, the primary addictive component of tobacco smoke, may functionally interact in the central nervous system and/or share a common mechanism of action. While nicotine initiates dependence by binding to and activating neuronal nicotinic acetylcholine receptors (nAChRs), ligand-gated cation channels normally activated by endogenous acetylcholine (ACh), ethanol is much less specific with the ability to modulate multiple gene products including those encoding voltage-gated ion channels, and excitatory/inhibitory neurotransmitter receptors. However, emerging data indicate that ethanol interacts with nAChRs, both directly and indirectly, in the mesocorticolimbic dopaminergic (DAergic) reward circuitry to affect brain reward systems. Like nicotine, ethanol activates DAergic neurons of the ventral tegmental area (VTA) which project to the nucleus accumbens (NAc). Blockade of VTA nAChRs reduces ethanol-mediated activation of DAergic neurons, NAc DA release, consumption, and operant responding for ethanol in rodents. Thus, ethanol may increase ACh release into the VTA driving activation of DAergic neurons through nAChRs. In addition, ethanol potentiates distinct nAChR subtype responses to $\mathrm{ACh}$ and nicotine in vitro and in DAergic neurons. The smoking cessation therapeutic and $\mathrm{nAChR}$ partial agonist, varenicline, reduces alcohol consumption in heavy drinking smokers and rodent models of alcohol consumption. Finally, single nucleotide polymorphisms in nAChR subunit genes are associated with alcohol dependence phenotypes and smoking behaviors in human populations. Together, results from pre-clinical, clinical, and genetic studies indicate that nAChRs may have an inherent role in the abusive properties of ethanol, as well as in nicotine and alcohol co-dependence.

Keywords: nicotine, alcoholism, acetylcholine, nicotinic receptors, mesolimbic dopamine system

\section{INTRODUCTION}

Alcoholism is the third leading cause of preventable mortality in the world (Mokdad et al., 2004). Worldwide, about 2 billion people consume alcohol, with 76.3 million who have diagnosable alcohol use disorders (AUDs). Additionally, when analyzing the global burden of this disease, alcohol causes 2.5 million deaths per year (4\% of the worldwide total) (World Health Organization, 2011). The estimated economic cost of alcoholism in the US alone, due to health care costs as well as productivity impacts such as lost wages, was $\$ 220$ billion in 2005 , which was significantly higher than cancer ( $\$ 196$ billion) or obesity ( $\$ 133$ billion) (CASA, 2000).

Interestingly, several reports from the 1980s to 1990s have estimated that $80 \%$ of alcohol-dependent people are also smokers (Bobo, 1992; Miller and Gold, 1998) and that smokers have an increased risk of developing AUDs (DiFranza and Guerrera, 1990; Grant et al., 2004). In addition, while the smoking rates in the general population of the U.S. have dramatically decreased over the past two decades, smoking has remained high in alcoholic individuals (Meyerhoff et al., 2006), with current estimates still between 70 and $75 \%$ (Bobo and Husten, 2000). These high rates of co-abuse of nicotine and alcohol have led some researchers to define this population as "alcoholic smokers" as compared to "smokers" (Littleton et al., 2007). Many hypotheses have been proposed as to the basis of the high rates of nicotine and alcohol co-abuse. For example, it is possible that alcohol use leads to nicotine use or vice versa (Tyndale, 2003), or that because alcohol and nicotine are legal and readily available, the likelihood of their co-use is increased (Funk et al., 2006). However, mounting genetic, pre-clinical, and clinical evidence indicates that neuronal nicotinic acetylcholine receptors (nAChRs), the molecular targets of nicotine that initiate dependence in smokers, may also contribute to alcohol's abusive properties. In addition, neuronal nAChRs may represent common molecular targets where nicotine and ethanol functionally interact, potentially explaining the widespread co-morbidity between smoking and alcohol consumption. The focus of this review is to highlight this evidence, summarize recent findings, and identify gaps in knowledge regarding the role of nAChRs in alcohol dependence and nicotine and alcohol co-abuse.

\section{NEURONAL nAChRS}

Neuronal nAChRs are ligand-gated cation channels that are activated by the endogenous neurotransmitter acetylcholine $(\mathrm{ACh})$ and the exogenous tertiary alkaloid nicotine (Albuquerque et al., 2009). They belong to the superfamily of Cys-loop ligandgated ion channels that include receptors for $\gamma$-amino butyric acid (GABA, the $G A B A_{A}$, and $G A B A_{C}$ receptor), glycine, and 
5-hydroxytryptamine (5-HT3) (Le Novere and Changeux, 1995; Changeux and Edelstein, 1998). These ligand-gated ion channels have similar structural and functional features. All subunits in this family contain a pair of disulfide-bonded cysteines separated by 13 residues (Cys-loop) in their extracellular amino terminus (Karlin, 2002).

Neuronal nAChRs, like all members of the cys-loop family of ligand-gated ion channels are formed by the arrangement of five subunits to create a central pore (Albuquerque et al., 2009). The structure of neuronal nAChRs is homologous to muscle nAChRs (Karlin, 2002), for which the atomic structure has been determined from electron microscopy studies from the fish electric organ (Torpedo nAChRs) (Miyazawa et al., 2003; Unwin, 2005). Each $\mathrm{nAChR}$ gene encodes a protein subunit consisting of a large aminoterminal extracellular domain composed of $\beta$-strands, four transmembrane $\alpha$-helices segments (M1-M4), a variable intracellular loop between M3 and M4, and an extracellular carboxy-terminus (Corringer et al., 2000) (Figure 1A). The extracellular N-terminus contains the ACh binding domain that forms a hydrophobic pocket located between adjacent subunits in an assembled receptor (Sine, 2002). The M2 segment of all five subunits forms the conducting pore of the channel, and regions in the M2 intracellular loop contribute to cation selectivity and channel conductivity (Corringer et al., 2000) (Figure 1B).

In vertebrates, 12 genes encoding 12 distinct neuronal $\mathrm{nAChR}$ subunits have been identified (Cholinergic Receptor Nicotinic Alpha: CHRNA2-10 and Cholinergic Receptor Nicotinic Beta: CHRNB2-4 encoding $\alpha 2-\alpha 10$ and $\beta 2-\beta 4$ nAChR subunits, respectively all of which can be found in humans and other mammals, except for $\alpha 8$ which has only been identified in avian species (Millar and Gotti, 2009). Subunits are classified as either $\alpha$-, by the presence of a Cys-Cys pair near the start of TM1, or non- $\alpha(\beta)$ when the Cys pair is missing (Le Novere and Changeux, 1995; Changeux and Edelstein, 1998).

Five subunits combine to form two classes of receptors: homomeric receptors containing only $\alpha$ subunits $(\alpha 7-\alpha 9)$ or heteromeric receptors that contain $\alpha$ and $\beta$ subunits ( $\alpha 2-\alpha 6$ and $\beta 2-\beta 4)$ (Dani and Bertrand, 2007) (Figures 1C,D). The most abundant subtypes in the brain are the low affinity $\alpha 7$ homomeric and high affinity $\alpha 4 \beta 2^{*}$ heteromeric nAChRs. An asterisk in nAChR nomenclature (i.e., $\alpha 4^{*}, \alpha 4 \beta 2^{*}$ ) indicates that other unidentified $\mathrm{nAChR}$ subunits may also be present and can be read as " $\alpha 4$ subunit containing nAChRs." Importantly, heteromeric nAChRs are incredibly complex as they can contain two or three alpha subunits co-assembled with two or three beta subunits. For example, $\alpha 4 \beta 2 \mathrm{nAChRs}$ can be formed by either two $\alpha$ and three $\beta$ subunits $\left[(\alpha 4)_{2}(\beta 2)_{3}\right]$ or three $\alpha$ and two $\beta$ subunits $\left[(\alpha 4)_{3}(\beta 2)_{2}\right]$ (Zwart and Vijverberg, 1998; Nelson et al., 2003; Moroni et al., 2006). Each stoichiometry of the nAChR exhibits distinct sensitivity to agonist: $\left[(\alpha 4)_{2}(\beta 2)_{3}\right]$ $\mathrm{nAChRs}$ have a higher sensitivity to agonist $\left(\mathrm{EC}_{50}=\sim 1 \mu \mathrm{MACh}\right)$; whereas $\left[(\alpha 4)_{3}(\beta 2)_{2}\right]$ nAChRs have a lower sensitivity to agonist $\left(\mathrm{EC}_{50}=\sim 100 \mu \mathrm{M}\right.$ ACh) (Buisson and Bertrand, 2001; Nelson et al., 2003; Moroni et al., 2006). In addition, more than one type of alpha and/or beta subunit may be present in a functional receptor. For example, a subtype identified in midbrain dopaminergic (DAergic) neurons contains $\alpha 4$ and $\beta 2$ subunits co-assembled with $\alpha 6$ and $\beta 3$ subunits to form the $\alpha 4 \alpha 6 \beta 2 \beta 3^{*} \mathrm{nAChR}$ (Salminen et al., 2004, 2007; Zhao-Shea et al., 2011; Liu et al., 2012). This subunit diversity allows for a vast array of $\mathrm{nAChR}$ subtypes each with distinct pharmacological and biophysical properties (McGehee and Role, 1995; Gotti et al., 2007).

Neuronal nAChRs can exist in three conformational states and are regulated by exposure to agonist: closed at rest, when the receptor has low affinity for agonist and the channel is closed; the active

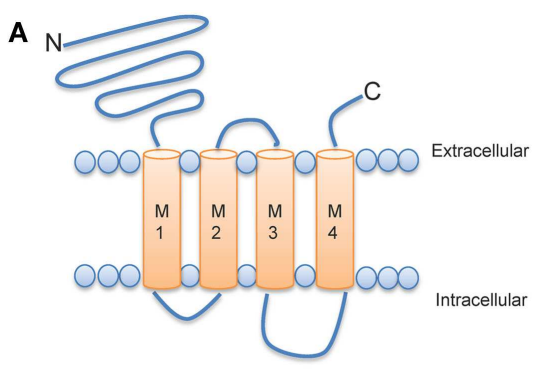

C

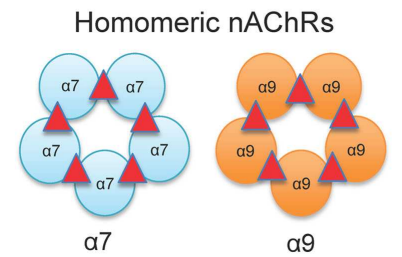

FIGURE 1 | Neuronal nAChR Structure. (A) Membrane topology of a neuronal nAChR subunit. Each nAChR subunit contains four transmembrane domains (M1-M4), an extracellular amino- and carboxy-terminus, and a prominent M3-M4 intracellular loop of variable length. (B) Five subunits coassemble to form a functional subunit. (C) Homomeric receptors consist of $\alpha$ subunits only and usually have low
B

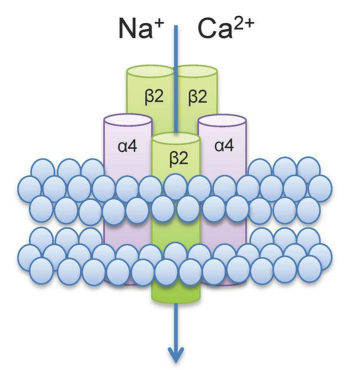

D Heteromeric nAChRs

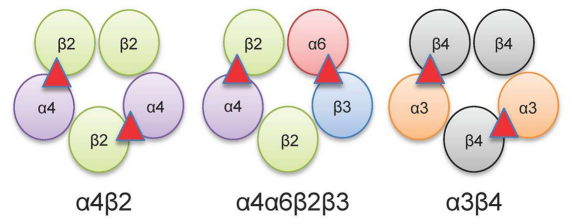

affinity for agonist. To date, only mammalian $\alpha 7, \alpha 9$, and $\alpha 10$ (not shown) subunits may form functional homomers. (D) The majority of high affinity nAChRs are heteromeric and consist of a combination of $\alpha$ and $\beta$ subunits. Importantly, multiple $\alpha$ subunits may coassemble with multiple $\beta$ subunits in the pentameric nAChR complex (illustrated here by $\alpha 4 \alpha 6 \beta 3 \beta 2$ ). ACh binding sites are depicted as red triangles. 
state, when agonist occupies the ligand binding site and the channel is open allowing cations to flow down their electrochemical gradient; and the desensitized state, when the channel is occluded and the receptor is unresponsive to ligand (Dani and Bertrand, 2007; Albuquerque et al., 2009).

Interestingly, while $\mathrm{nAChRs}$ mediate fast, direct synaptic transmission at neuromuscular junctions and autonomic ganglia, there are very few examples of fast nicotinic transmission in the mammalian brain (Dani and Bertrand, 2007). However, neuronal nAChRs are expressed at the soma in neurons where they presumably modulate excitability directly. In addition, a significant proportion of $\mathrm{nAChRs}$ are located on presynaptic terminals (Role and Berg, 1996) where they facilitate $\mathrm{Ca}^{2+}$ dependent release of neurotransmitters (McGehee et al., 1995; Wonnacott, 1997). This may occur indirectly as a result of $\mathrm{Na}^{+}$influx causing membrane depolarization and activation of voltage-gated $\mathrm{Ca}^{2+}$ channels or directly through $\mathrm{Ca}^{2+}$ influx through the channel itself (Albuquerque et al., 2009).

\section{ETHANOL MODULATION OF NEURONAL nAChRS: IN VITRO STUDIES}

While ethanol modulates several ligand-gated ion channels including $\mathrm{GABA}_{\mathrm{A}}, \mathrm{NMDA}$, and $5-\mathrm{HT}_{3}$ receptors (For a review see Spanagel, 2009), ethanol also potently modulates nAChRs at low concentrations of ethanol $(100 \mu \mathrm{M}-10 \mathrm{mM})$, identifying $\mathrm{nAChRs}$ as potential targets for ethanol action (Nagata et al., 1996). In heterologous expression systems, the effect of ethanol on nAChRs depends on the subunit composition of the nAChR. Expression of different combinations of human neuronal $\mathrm{nAChR}$ alpha and beta subunits in Xenopus oocytes, indicate acute ethanol (75 mM) potentiates ACh-induced current of $\alpha 2 \beta 4, \alpha 4 \beta 4, \alpha 2 \beta 2$, and $\alpha 4 \beta 2$ nAChRs while lower concentrations of ethanol (20$50 \mathrm{mM}$ ) inhibits nicotine-induced current of $\alpha 7 \mathrm{nAChRs}$ and all concentrations of ethanol tested have no effect on $\alpha 3 \beta 2$ or $\alpha 3 \beta 4$ nAChRs (Cardoso et al., 1999). Similar ethanol effects on heterologous expression of rat nAChRs in Xenopus oocytes have been observed except that ethanol could potentiate or inhibit $\alpha 3 \beta 4$ nAChRs at all ethanol concentrations tested likely reflecting oocyte batch to batch variability. In cultured rat cortical neurons, AChevoked nAChR currents insensitive to $\alpha$-bungarotoxin ( $\alpha$-Bgtx), which blocks $\alpha 7$ nAChRs (i.e., heteromeric nAChRs) are significantly enhanced by physiologically relevant concentrations of ethanol while nAChRs sensitive to $\alpha$-Bgtx (i.e., $\alpha 7$ homomeric nAChRs) are inhibited (Aistrup et al., 1999). Although not tested directly the $\alpha$-Bgtx insensitive current profile was most similar to native $\alpha 4 \beta 2 *$ nAChRs (Marszalec et al., 1999).

Similar to other ligand-gated ion channels, ethanol potentiation of nAChRs is hypothesized to be a result of the ethanol-induced stabilization of the open channel state of the receptor (Wu et al., 1994; Forman and Zhou, 1999; Zuo et al., 2004). Site directed cysteine mutagenesis and covalent labeling with sulfhydryl reagents indicate that amino acid residues in the pore forming $\mathrm{M} 2$ region of neuronal $\mathrm{nAChR}$ at least partly contribute to the ethanol binding pocket (Borghese et al., 2002, 2003a,b). While individual amino acid residues forming the ethanol binding pocket may be distinct from other cys-loop receptors, the overall motif, the extracellular domain of $\mathrm{M} 2$, is critical for ethanol actions on nAChRs as well as $\mathrm{GABA}_{\mathrm{A}}$ and glycine receptors (Borghese et al., 2003a). Additionally, it is possible that the ethanol-induced inhibitory effect seen with $\alpha 7 \mathrm{nAChRs}$ is due to the inherently fast desensitization rate of these receptors, implying that ethanol inhibition results in enhanced desensitization (Dopico and Lovinger, 2009). Thus, these and in vivo studies discussed below, suggest that ethanol modulation of nAChRs, either by enhancing or inhibiting function, may contribute to (1) the inherent mechanism of action of ethanol reward and (2) the common co-abuse of nicotine and alcohol.

\section{NEURONAL $n A C h R$ EXPRESSION IN THE MESOCORTICOLIMBIC DA PATHWAY}

Although neuronal nAChRs are expressed throughout the CNS, most studies focusing on the role of nAChRs in addiction have examined the mesocorticolimbic "reward" circuitry. Indeed, it is widely accepted that the mesocorticolimbic dopamine system plays a central role in modulating the rewarding effects of drugs of abuse (Wise and Bozarth, 1987; Koob, 1992).

The ventral tegmental area (VTA) is located in the ventral midbrain, medial to the substantia nigra, and ventral to the red nucleus. It is referred to as an "area" and not considered to be a "nucleus" because the cryoarchitecture of the region is not well defined such that the boundaries of the VTA are determined by its neighboring structures (Fields et al., 2007; Ikemoto, 2007). Within the VTA are two main cell populations, DAergic projection neurons, which comprise $\sim 60 \%$ of cells in this region (Swanson, 1982), as well as local GABAergic interneurons and projection neurons (Carr and Sesack, 2000; Margolis et al., 2006a). The VTA receives inputs from regions throughout the CNS (Geisler and Zahm, 2005) including glutamatergic projections from the prefrontal cortex (PFC) (Sesack and Pickel, 1992), as well as glutamatergic, cholinergic, and GABAergic projections from two groups of mesopontine tegmental area neurons, the pedunculopontine tegmental nucleus (PPTg) and the laterodorsal tegmental nucleus (LDT; Figure 2A) (Cornwall et al., 1990; Semba and Fibiger, 1992; Oakman et al., 1995). Other regions projecting to the VTA include the nucleus accumbens (NAc), amygdala, ventral pallidum, superior colliculus, and lateral hypothalamus (For a review see Fields et al., 2007). Additionally, the lateral habenula (LH), a small nucleus that is a part of the epithalamus, has been shown to project to midbrain areas, and modulate the release of DA from the VTA and substantia nigra pars compacta (Herkenham and Nauta, 1979; Ji and Shepard, 2007; Matsumoto and Hikosaka, 2007).

Neurons in the VTA primarily project to the ventromedial striatum including the NAc shell and core as well as smaller projections to the PFC, hippocampus, entorhinal cortex, and lateral septal areas (Fields et al., 2007). Furthermore, studies using retrograde markers have shown that distinct groups of neurons originating in the VTA project to specific forebrain regions (Fallon et al., 1984; Margolis et al., 2006b). Projections to the NAc contain the largest proportion of DA neurons, with 65-85\% being DAergic, while the PFC projections are only 30-40\% DAergic (Swanson, 1982; Fallon et al., 1984). The remaining component of VTA afferents to the NAc and PFC contain GABAergic neurons (Carr and Sesack, 2000). The VTA is not a homogeneous region and can be divided 


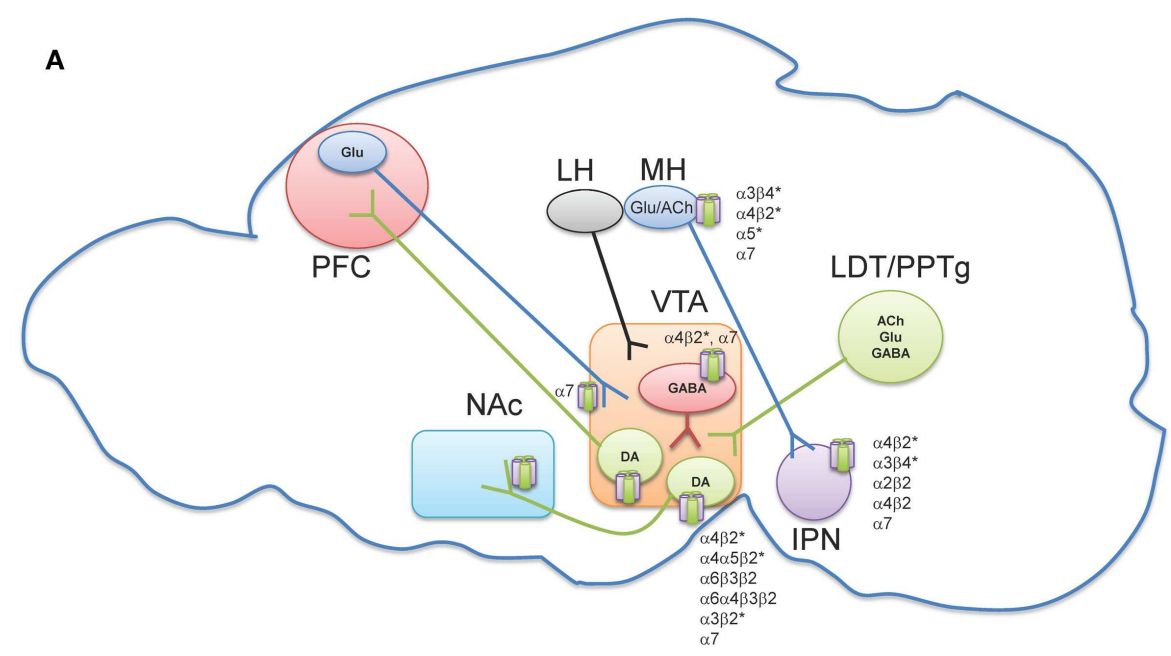

B

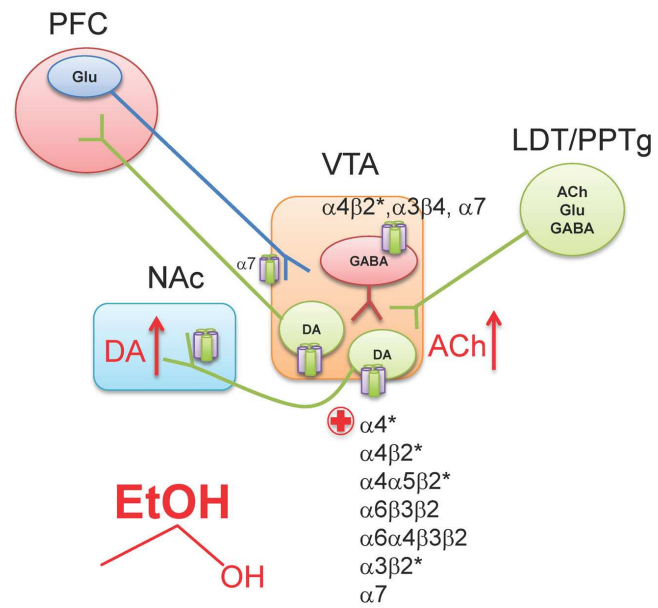

FIGURE 2 | Neuronal nAChR expression in the reward pathway. (A) Sagittal rodent section illustrating the simplified mesocorticolimbic and habenulo-peduncular circuitry. Known neuronal nAChR subtypes expressed in different nuclei are indicated [for a review see (Millar and Gotti, 2009)]. (B) In the VTA, alcohol stimulates DAergic neurons at least, in part, via $\mathrm{nAChR}$ activation. Ethanol increases ACh release (red arrow, presumably through cholinergic projection from the LDT/PPTg) which in turn activates $\mathrm{nAChRs}$ on DAergic neurons driving activity. In addition, ethanol potentiates ACh activation at high affinity $\alpha 4 \beta 2^{*}$ $n A C h R s$ (red plus sign). The effect of alcohol on additional nAChRs in the VTA is unknown. This confluence of events in combination with other effects of alcohol in the VTA ultimately increases DA release in NAc (red arrow). VTA, Ventral tegmental area; NAc, Nucleus accumbens; PFC, Prefrontal cortex; LH, Lateral habenula; $\mathrm{MH}$, Medial habenula; IPN, Interpeduncular nucleus; LDT, Lateral dorsal tegmentum; PPTg, Pedunculopontine tegmentum. into three sub-regions, the anterior VTA, posterior VTA, and the tail VTA. Additionally, evidence indicates that each region may project to distinct regions of the striatum and may also respond differently to drugs of abuse including nicotine and ethanol (Rodd et al., 2004a, 2010; Ikemoto, 2007; Shabat-Simon et al., 2008; ZhaoShea et al., 2011). Importantly, nAChRs are robustly expressed in the VTA. DAergic neurons contain several nAChR subtypes including $\alpha 4 \beta 2^{*}, \alpha 4 \alpha 5 \beta 2^{*}, \alpha 4 \alpha 6 \beta 2^{*}, \alpha 6 \beta 2^{*}, \alpha 3 \beta 2^{*}$, and $\alpha 7$ (Picciotto et al., 1998; Champtiaux et al., 2002; Marubio et al., 2003; Grady et al., 2007; Gotti et al., 2010; Zhao-Shea et al., 2011; Liu et al., 2012); whereas GABAergic VTA neurons express $\alpha 4 \beta 2, \alpha 7$, and $\alpha 3 \beta 4$ nAChRs (Figure 2A) (Klink et al., 2001; Mansvelder et al., 2002; Pidoplichko et al., 2004; Nashmi et al., 2007; Tolu et al., 2012).

\section{NEURONAL nAChRs AND ETHANOL: IN VIVO STUDIES}

The rewarding or reinforcing properties of ethanol and nicotine, as with most drugs of abuse, are associated with an increase in DA release in the NAc (Di Chiara and Imperato, 1988; Lewis and June, 1990; Benwell and Balfour, 1992; Samson et al., 1992; Diana et al., 1993; Weiss et al., 1993; Lanca, 1994; Pontieri et al., 1996). Both drugs increase the baseline firing frequency of VTA DAergic neurons and also increase the firing pattern from phasic to bursting, facilitating NAc DA release (Mereu et al., 1984; Gessa et al., 1985; Foddai et al., 2004; Exley et al., 2011; Li et al., 2011). Although the precise role of NAc DA release in reward is still under debate (Schultz, 2004; Salamone and Correa, 2012), ethanol- and nicotine-induced release of DA is critical for the onset and maintenance of dependence. Pharmacological blockade 
of DA receptors, destruction of DA neurons or lesioning of the NAc reduces ethanol and nicotine self-administration (Kiianmaa, 1978; Koob and Weiss, 1990; Corrigall and Coen, 1991; Corrigall et al., 1992, 1994; Rassnick et al., 1993; Ikemoto et al., 1997). In addition, rats will self-administer ethanol or nicotine directly into the VTA (Gatto et al., 1994; Ikemoto et al., 2006), and more specifically, the posterior VTA (Rodd et al., 2004b).

It is becoming increasingly clear that nicotine dependence is initiated by activation of DAergic neurons via nAChRs containing $\alpha 4$ and $\beta 2$ subunits with some contribution of $\alpha 6^{*}$ nAChRs (Picciotto et al., 1998; Tapper et al., 2004; Maskos et al., 2005; Pons et al., 2008; Exley et al., 2011; Tolu et al., 2012). In the context of this review, we will not focus further on the mechanistic bases of nicotine dependence; rather we direct readers to a recent review article (De Biasi and Dani, 2011). In contrast to nicotine, multiple mechanisms underlying ethanol-mediated activation of VTA DAergic neurons have been proposed including modulation of intrinsic ion channels within these neurons, as well as ethanol-mediated alterations in synaptic input, both excitatory and inhibitory (Okamoto et al., 2006; Job et al., 2007; Xiao and Ye, 2008; Xiao et al., 2009; Rodd et al., 2010; Theile et al., 2011; Guan et al., 2012). However, cholinergic signaling through nAChRs also contributes to NAc DA release and ethanol reinforcement (Blomqvist et al., 1992, 1993, 1996; Ericson et al., 1998; Nadal et al., 1998; Dyr et al., 1999; Le et al., 2000; Soderpalm et al., 2000; Farook et al., 2009a; Kuzmin et al., 2009). One of the most consistent findings implicating nAChRs in ethanol behaviors associated with reward/reinforcement is that the non-specific nAChR antagonist, mecamylamine, reduces ethanol consumption and blocks ethanol-induced DA release in the NAc. Originally discovered by pioneering work of Soderpalm and Engel, systemic mecamylamine significantly reduces ethanol-mediated extracellular DA release in the NAc (Blomqvist et al., 1993), and reduces ethanol consumption in rats (Blomqvist et al., 1996). The effect of mecamylamine is localized to the VTA, as local infusion of the antagonist in rat midbrain but not NAc reduces NAc DA release elicited by ethanol (Blomqvist et al., 1997). VTA infusion of mecamylamine also reduces rat operant responding for ethanol and ethanol-associated cues, as well as consumption during relapse (Lof et al., 2007; Kuzmin et al., 2009). In mice, mecamylamine delivered systemically reduces ethanol consumption in C57Bl/6J mice in the restricted access ethanol consumption "drinking in the dark" (DID) paradigm (Hendrickson et al., 2009), a model of binge drinking (Rhodes et al., 2005, 2007), as well as in the two-bottle choice consumption assay (Farook et al., 2009a). What is mecamylamine's mechanism of action in reducing ethanol consumption? In mice, mecamylamine apparently blocks activation of VTA DAergic neurons by ethanol as measured by c-Fos induction after challenge with an intraperitoneal injection (i.p.) of ethanol (Hendrickson et al., 2009). More recently, it has been demonstrated that mecamylamine blocks ethanol-mediated activation of VTA DAergic neurons in mouse midbrain slices (Liu et al., 2013). Mecamylamine also blocks the ability of ethanol to condition a place preference in mice (Bhutada et al., 2012). Thus, these data suggest that $\mathrm{nAChR}$ expressed in the VTA contribute to ethanol activation of DAergic neurons and ethanol reward. The effects of mecamylamine in these pre-clinical models may have predictive validity as patients administered mecamylamine report reduced pleasurable effects of alcoholic beverages (Chi and de Wit, 2003). As discussed above, ethanol is not a direct agonist at nAChRs; rather it potentiates or inhibits nAChRs depending on subtype. Thus, nAChR involvement in ethanol reward implies that ethanol must increase ACh concentrations in brain regions involved in reward/reinforcement. To date, one study has measured extracellular concentrations of ACh in the VTA of rats that voluntarily consumed ethanol and found that ACh levels were increased after ethanol consumption and shortly thereafter, DA concentrations were elevated in the NAc as well (Larsson et al., 2005). These data indicate that the increase in VTA ACh could drive activation of DAergic neurons through nAChRs (Figure 2B). While the predominant VTA cholinergic afferents project from the PPTg and LDT area (Oakman et al., 1995), brain regions that have also been implicated in mediating natural as well as drug-reward behavior (Yeomans et al., 1993), additional experiments will be needed to verify that these inputs mediate ethanol-induced increases in VTA ACh. In addition, the mechanism by which ethanol could elicit an increase in ACh release into the VTA is unknown and warrants further study.

\section{NEURONAL nAChRs AND ALCOHOL: IDENTIFYING RELEVANT SUBTYPES: PHARMACOLOGY}

Because mecamylamine blocks virtually all subtypes of nAChRs, it provides little insight into the subunit composition of key nAChRs involved in ethanol activation of DAergic neurons or ethanol behaviors associated with the VTA such as consumption. Thus, several studies have used additional, more selective nAChR antagonists, in an effort to uncover the nAChR subtype(s) that may be involved in ethanol's mechanism of action (Table 1). Studies in VTA responses to nicotine indicate that DAergic neurons contain several nAChR subtypes including $\alpha 4 \beta 2^{*}, \alpha 4 \alpha 5 \beta 2^{*}, \alpha 4 \alpha 6 \beta 2^{*}$, $\alpha 6 \beta 2^{*}, \alpha 3 \beta 2^{*}$, and $\alpha 7$ (Picciotto et al., 1998; Champtiaux et al., 2002; Marubio et al., 2003; Grady et al., 2007; Gotti et al., 2010; Zhao-Shea et al., 2011; Liu et al., 2012). Identifying the precise subunit composition of nAChRs involved in ethanol consumption and activation of VTA DAergic neurons is challenging due to the sheer number of potential subunit combinations that may be expressed in the VTA. However, identifying one or more nAChR subtypes involved in ethanol activation of VTA and/or reward may lead to novel targets to reduce consumption. Systemic injection or VTA infusion of the competitive $\alpha 4 \beta 2 \mathrm{nAChR}$ antagonist, dihydro$\beta$-erythroidine $(\mathrm{DH} \beta \mathrm{E})$, in rats, fails to reduce ethanol-mediated DA release in the NAc and ethanol intake (Ericson et al., 2003; Chatterjee et al., 2011). In addition, low doses of $\mathrm{DH} \beta \mathrm{E}$ also have little effect on operant responding for ethanol in rats, although a higher dose can reduce responding (Kuzmin et al., 2009). Systemic injection of $\mathrm{DH} \beta \mathrm{E}$ does not reduce consumption in mice as measured in the DID assay nor ethanol-induced NAc DA release (Larsson et al., 2002; Hendrickson et al., 2009). Together these data suggest that $\alpha 4 \beta 2 \mathrm{nAChRs}$ may not be critical for ethanol reward and consumption behavior. However, sensitivity of $\alpha 4 \beta 2 * \mathrm{nAChR}$ blockade by $\mathrm{DH} \beta \mathrm{E}$ is dependent on the stoichiometry of the receptor and the expression of other non- $\alpha 4 \beta 2$ subunits that may also be present in an $\alpha 4 \beta 2 *$ nAChR complex (Harvey and Luetje, 1996; Harvey et al., 1996; Le et al., 2000; Larsson et al., 2002; Ericson 
Table 1 | Neuronal nAChR ligands that modulate alcohol behaviors.

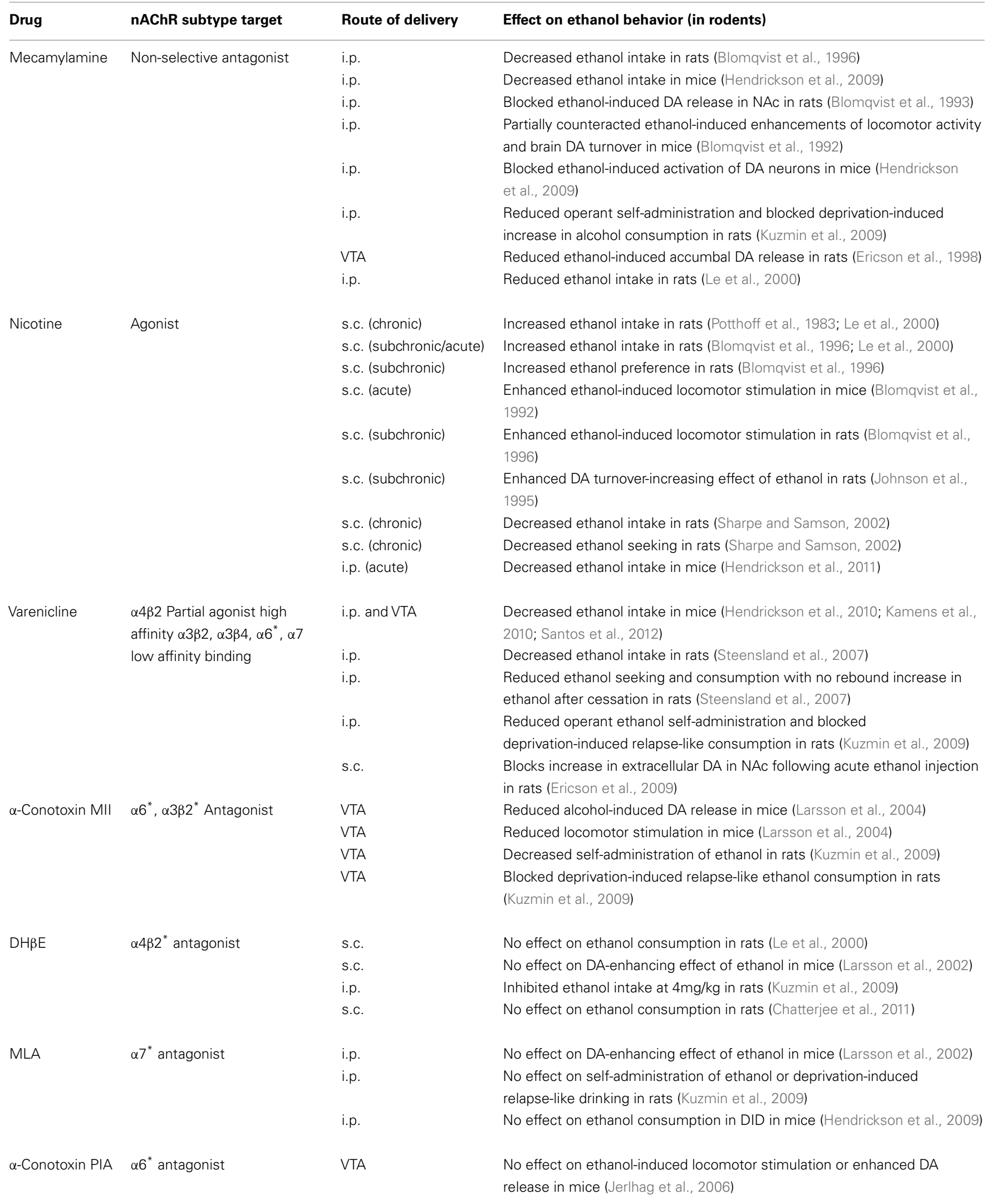


Table 1 | Continued

\begin{tabular}{|c|c|c|c|}
\hline Drug & nAChR subtype target & Route of delivery & Effect on ethanol behavior (in rodents) \\
\hline CP-601932 & $\begin{array}{l}\alpha 3 \beta 4 \text { and } \alpha 4 \beta 2 \text { high affinity } \\
\text { partial agonist }\end{array}$ & S.c. & $\begin{array}{l}\text { Decreased ethanol consumption and operant self-administration in rats } \\
\text { (Chatterjee et al., 2011) }\end{array}$ \\
\hline PF-4575180 & $\begin{array}{l}\alpha 3 \beta 4 \text { high affinity partial } \\
\text { agonist }\end{array}$ & S.c. & $\begin{array}{l}\text { Decreased ethanol consumption and operant self-administration in rats } \\
\text { (Chatterjee et al., 2011) }\end{array}$ \\
\hline \multirow[t]{2}{*}{ Lobeline } & $\begin{array}{l}\text { Non-selective antagonist, } \\
\text { particularly at } \beta 2^{*} \mathrm{nAChRs}\end{array}$ & S.c. & $\begin{array}{l}\text { Reduced ethanol consumption in DID and during continuous ethanol } \\
\text { access in mice (Farook et al., 2009b; Sajja and Rahman, 2011) }\end{array}$ \\
\hline & & S.c. & $\begin{array}{l}\text { Reduced ethanol-induced DA and its metabolite levels in ventral striatum in } \\
\text { mice (Sajja et al., 2010) }\end{array}$ \\
\hline \multirow[t]{2}{*}{ Cytisine } & $\begin{array}{l}\text { Low-efficacy partial agonist } \\
\text { with high affinity for } \alpha 4 \beta 2^{*}\end{array}$ & S.c. & $\begin{array}{l}\text { Reduced ethanol consumption in DID in mice and during continuous } \\
\text { ethanol access in mice (Hendrickson et al., 2009; Sajja and Rahman, 2011) }\end{array}$ \\
\hline & $\begin{array}{l}\text { nAChRs. Full agonist at } \beta 4^{*} \\
\text { and } \alpha 7^{*} \text { nAChRs }\end{array}$ & S.c. & Reduced ethanol-induced DA and its metabolite in mice (Sajja et al., 2010) \\
\hline Sazetidine-A & $\begin{array}{l}\text { Highly selective } \alpha 4 \beta 2 \\
\text { desensitizer }\end{array}$ & S.c. & Reduces alcohol intake in rats (Rezvani et al., 2010) \\
\hline
\end{tabular}

et al., 2003; Moroni et al., 2006; Lof et al., 2007; Kamens and Phillips, 2008). The $\alpha 7$ selective antagonist, methyllycaconitine (MLA), does not affect ethanol-mediated behaviors including consumption, ethanol-induced DA release in NAc and ethanol operant responding in rats, as well as, consumption in mice. While caution with interpretation of these results is warranted due to data indicating higher concentrations of MLA may also antagonize non- $\alpha 7$ nAChRs (of an unknown nAChR subtype that may include $\alpha 6$ and/or $\alpha 3$ subunits (Mogg et al., 2002)), homomeric $\alpha 7$ nAChRs may not be involved in ethanol reinforcement (Larsson et al., 2002; Hendrickson et al., 2009; Kuzmin et al., 2009). On the other hand, the $\alpha 3 \beta 2^{*}, \beta 3^{*}$, and $\alpha 6^{*}$ subtype-selective antagonist, $\alpha$-conotoxin MII (Cartier et al., 1996), when infused into the VTA does inhibit ethanol consumption, operant responding, and DA release in the NAc of rats (Larsson et al., 2004, 2005; Kuzmin et al., 2009) and reduce ethanol-induced locomotor stimulation and increases in NAc DA release in mice (Larsson et al., 2004; Jerlhag et al., 2006). Importantly, recent data indicate that approximately half of $\alpha$ conotoxin MII-sensitive nAChRs in the striatum also contain the $\alpha 4$ subunit (Grady et al., 2007; Salminen et al., 2007) and deletion of $\beta 2^{*}$ nAChRs nearly abolishes $\alpha$-conotoxin MII binding in the VTA (Marubio et al., 2003). However, infusion of $\alpha$-conotoxin PIA, which may have more selectivity for $\alpha 6^{*}$ nAChRs than $\alpha 3^{*}$ nAChRs (Dowell et al., 2003), failed to reduce ethanol-induced DA release in NAc when infused in the VTA suggesting that $\alpha 3^{*}$ nAChRs may be more critical for ethanol reward. Finally, systemic injection of the $\alpha 3 \beta 4^{*}$ nAChR-selective antagonist 18 -methoxycoranaridine (18-MC) reduces ethanol consumption in alcohol-preferring rats (Rezvani et al., 1997). However, direct infusion of 18-MC into the VTA fails to reduce alcohol consumption (Carnicella et al., 2010 ) in rats consistent with data indicating low expression of $\beta 4^{*}$ nAChRs in VTA DAergic neurons (Gotti et al., 2010; Zhao-Shea et al., 2011).

\section{NEURONAL nAChRs AND ALCOHOL: IDENTIFYING RELEVANT SUBTYPES: MOUSE GENETICS}

Behavioral studies in genetically engineered mice have also been used to glean information on $\mathrm{nAChR}$ subtypes that may be involved in alcohol consumption and reward. Mice that do not express chrnb2, the gene encoding the $\mathrm{nAChR} \beta 2$ subunit $(\beta 2 \mathrm{KO})$ consume and prefer ethanol in a $24 \mathrm{~h}$ access two-bottle choice paradigm similar to wild-type (WT) littermates indicating that $\beta 2^{*} \mathrm{nAChR}$ may not play a role in baseline ethanol consumption in this assay (Kamens et al., 2010). Similarly, $\alpha 6 \mathrm{KO}$ and $\beta 3 \mathrm{KO}$ mice consume ethanol similar to WT in a $24 \mathrm{~h}$ access two-bottle choice consumption assay (Kamens et al., 2012). Female $\alpha 7 \mathrm{KO}$ mice consume significantly less ethanol in this paradigm compared to female WT littermates; whereas male $\alpha 7 \mathrm{KO}$ and WT mice consume similar amounts of ethanol indicating a potential gender effect of $\alpha 7 \mathrm{nAChRs}$ on ethanol consumption (Kamens et al., 2010). $\alpha 5 \mathrm{KO}$ mice do not differ in acute ethanol consumption, as measured by the DID assay, compared to WT (Santos et al., 2012). Together, these data indicate that nAChRs containing $\alpha 5$, $\alpha 6, \beta 2$, or $\beta 3$ subunits may not be critical for ethanol consumption per se. However, as nAChRs are robustly expressed in a variety of brain regions, subunit compensation may occur in a $\mathrm{KO}$ mouse background (Drago et al., 2003). Thus, these results will need to be verified using shRNAs to knock-down nAChR subunits in discreet brain regions. Interestingly, sleep time elicited by high doses of ethanol is increased in $\alpha 6$ and $\alpha 5$, but not $\beta 3 \mathrm{KO}$ mice compared to their WT littermates indicating a role for $\alpha 6^{*}$ and $\alpha 5^{*} \mathrm{nAChR}$ in alcohol-induced sedation (Kamens et al., 2012; Santos et al., 2012).

In contrast to the majority of $\mathrm{KO}$ models discussed above, acute ethanol consumption in the DID paradigm is significantly less in $\alpha 4 \mathrm{KO}$ mice compared to WT for high (20\%) but not low (2\%) concentrations of ethanol implicating a role for $\alpha 4^{*} \mathrm{nAChR}$ in ethanol consumption (Hendrickson et al., 2010, 2011). In addition, the 
ability of ethanol to condition a place preference in $\alpha 4 \mathrm{KO}$ mice is reduced compared to WT. Conversely, in mice harboring a point mutation in $\alpha 4^{*} \mathrm{nAChRs}$ that renders receptors hypersensitive to agonist [the Leu9'Ala $\alpha 4$ knock-in line (Tapper et al., 2004; Fonck et al., 2005)], a sub-threshold dose of ethanol is sufficient to condition a place preference indicating that $\alpha 4^{*} \mathrm{nAChRs}$ modulate alcohol reward (Liu et al., 2013). Consistent with behavioral data, ethanol activation of VTA DAergic neurons is reduced in $\alpha 4 \mathrm{KO}$ midbrain slices and more robust in Leu9'Ala midbrain slices. Finally, ethanol potentiates the response to bath applied $\mathrm{ACh}$ in midbrain DAergic neurons and potentiation is abolished in DAergic neurons of $\alpha 4 \mathrm{KO}$ mice (Liu et al., 2013). Together, these data indicate that $\alpha 4^{*}$ nAChRs in VTA DAergic neurons may contribute to ethanol activation of the VTA and alcohol reward although additional experiments are needed to confirm that the observed difference in ethanol-mediated behaviors in these mouse models are due to $\alpha 4^{*}$ nAChRs in the VTA as these receptors are expressed throughout the CNS (Baddick and Marks, 2011).

\section{NICOTINE AND ALCOHOL INTERACTIONS: IN VIVO STUDIES}

Human studies have shown that individuals dependent on alcohol have higher rates of nicotine dependence (Room, 2004), and smokers tend to consume more ethanol than non-smoking alcohol users (York and Hirsch, 1995). Unlike the majority of clinical studies, nicotine administration can either increase ethanol intake (Potthoff et al., 1983; Blomqvist et al., 1996; Smith et al., 1999; Le et al., 2000; Clark et al., 2001; Ericson et al., 2003), or decrease ethanol intake (Nadal et al., 1998; Dyr et al., 1999; Sharpe and Samson, 2002) in rats. These conflicting results have led to a complex and interesting questions: under what conditions (i.e., time delay between nicotine and ethanol, dose of nicotine, length of ethanol presentation, acute versus chronic nicotine/ethanol etc.) does nicotine increase ethanol intake, and what conditions cause a decrease in ethanol intake?

Blomqvist et al. (1996) demonstrated that daily nicotine during ethanol deprivation and ethanol reinstatement increases ethanol intake and preference in rats shown to have a medium baseline preference $(25-65 \%)$ for ethanol over water. Similarly, Le et al. (2003) demonstrated that rats increased lever presses for ethanol during the course of daily nicotine injection paired 15 min prior to an operant session. These data are in agreement with various other experiments in which nicotine was given either constantly or repeatedly (Potthoff et al., 1983; Smith et al., 1999; Ericson et al., 2000; Olausson et al., 2001). In rats, nicotine can also reinstate alcohol seeking after extinction and increase ethanol selfadministration when administered during an ethanol deprivation period (Lopez-Moreno et al., 2004). Interestingly, rats given nicotine only during the relapse period, once self-administration has resumed after a deprivation period, consume less ethanol, and rats given nicotine during both abstinence and relapse increased ethanol intake compared to control (Alen et al., 2009).

In contrast, Sharpe and Samson demonstrated that ethanol intake and lever pressing during operant ethanol selfadministration are both decreased after a high dose of nicotine $(0.7 \mathrm{mg} / \mathrm{kg}$, subcutaneous injection (s.c.), expressed as free base nicotine) $30 \mathrm{~min}$ prior to ethanol self-administration, and with a lower dose of nicotine $(0.35 \mathrm{mg} / \mathrm{kg}$, s.c.). While locomotor depression by nicotine could potentially confound the interpretation of decreased ethanol self-administration, this is unlikely as nicotine injections did not decrease sucrose self-administration. Thus, Sharpe and Samson (2002) propose that nicotine could be acting as a reinforcer of ethanol, decreasing the amount of ethanol necessary to achieve satiety. This is in agreement with other studies in which nicotine is administered either immediately prior to, or within $30 \mathrm{~min}$ of, ethanol presentation or self-administration (Nadal et al., 1998; Damaj, 2001).

To reconcile differences in nicotine effects on ethanol consumption and self-administration, Hauser et al. demonstrated that acute nicotine administration affects ethanol seeking and relapse in a time-dependent manner. Nicotine injection immediately prior to an ethanol operant self-administration session in ethanol preferring rats elicits reduced responding for ethanol compared to a saline injection; whereas nicotine exposure $4 \mathrm{~h}$ prior will increase responses (Hauser et al., 2012). These data indicate that acute nicotine may initially act as a substitute for ethanol at the immediate time-point causing a reduction in craving for ethanol and, at the later time-point, nicotine may lead to desensitization of nAChRs in the brain, enhancing ethanol seeking.

As in rats, acute nicotine immediately prior to presentation of ethanol in the DID paradigm reduces consumption in mice (Hendrickson et al., 2009); whereas chronic nicotine treatment increases consumption (Sajja and Rahman, 2012). The reduction of ethanol consumption is mediated by nAChRs containing the $\alpha 4$ subunit: nicotine fails to reduce consumption in $\alpha 4 \mathrm{KO}$ mice; whereas acute sub-threshold nicotine doses are sufficient to reduce consumption in Leu9'Ala mice (Hendrickson et al., 2011). The effect of acute nicotine activates the posterior VTA as measured by increased cFos in mouse VTA DAergic neurons while an additional injection of ethanol does not further activate these neurons, consistent with nicotine substituting for ethanol during this treatment schedule (Hendrickson et al., 2009).

The mechanistic basis of chronic nicotine on ethanol consumption is unclear. However, nicotine potentiates the response to ethanol in VTA DAergic neurons (Clark and Little, 2004) and repeated nicotine infusion into the posterior VTA increases the stimulatory effects of ethanol (Ding et al., 2012). These data indicate that chronic nicotine treatment may actually increase the reinforcing/rewarding properties of alcohol. Interestingly, chronic nicotine upregulates midbrain nAChRs which may lead to increased DAergic neuron activation by ethanol (Nashmi et al., 2007).

\section{NEURONAL nAChR LIGANDS FOR REDUCING ETHANOL CONSUMPTION}

While several areas of alcoholism research exist, the end goal of the majority of research is to identify new and improved treatment options for those suffering from alcoholism. Currently, there are three FDA approved medications for treating alcoholism. The first, disulfiram, was approved in 1954, and is classified as an antirelapse medication (Christensen et al., 1991). It is an acetaldehyde dehydrogenase inhibitor, which after drinking alcohol allows the buildup of acetaldehyde in the blood, causing symptoms including headache, nausea, vomiting, weakness, mental confusion, or anxiety (Christensen et al., 1991). However, in recent years, many 
physicians have stopped prescribing this drug because of the severe symptoms it causes and the fact that if a patient wished to drink again, they could simply not take their medication. Naltrexone, available since 1994, is a competitive opioid receptor antagonist that works by decreasing the euphoric effects produced by alcohol. It is considered to be an anti-relapsing drug because it decreases heavy drinking in patients with alcoholism and prevents relapse to heaving drinking (O'Malley et al., 1992; Volpicelli et al., 1992). The third drug, acamprosate, is a partial agonist of NMDA glutamate receptors and an antagonist of metabotropic glutamate receptors and is thought to act as an anti-craving medication by inhibiting glutamate signaling (Mason, 2003; Mason et al., 2006). While European studies have reported modest benefits with acamprosate, these studies have not been reproducible in the US (Pettinati et al., 2006).

Unfortunately, while these medications have been effective for some, only $20-30 \%$ of treated patients respond to the anti-craving and anti-relapsing compounds (Spanagel, 2009). Interestingly, new studies have shown that people with different genetic profiles may drink for different reasons, and also that they may respond better to one type of medication versus another. For example, populations with a specific type of mu opioid receptor respond to naltrexone better than others, and this group has been described as "feel good drinkers" (Oslin et al., 2006; Anton et al., 2008). Another population of alcoholics report that they drink to relieve feelings of stress and anxiety (Kuehn, 2009) for which new medications are currently being tested (George et al., 2008). This large variability in patient response is a driving force in identifying new molecular targets for improved pharmacotherapeutic drugs. Consequently, the main focus of alcoholism treatments has been to restore the balance to the different biochemical pathways in the brain that are disrupted during alcohol dependence.

Varenicline, an $\alpha 4 \beta 2$ partial agonist clinically approved as a smoking cessation therapeutic (Coe et al., 2005; Gonzales et al., 2006; Jorenby et al., 2006; Tonstad et al., 2006; Steensland et al., 2007), can reduce ethanol intake, ethanol seeking, and cue-induced ethanol reinstatement in rats (Steensland et al., 2007; Wouda et al., 2011) and ethanol consumption in mice (Hendrickson et al., 2010; Kamens et al., 2010; Santos et al., 2012). In addition, varenicline can also reduce the enhancing effect of chronic nicotine on ethanol self-administration in rats (Bito-Onon et al., 2011). Coupled with clinical data indicating that varenicline reduces ethanol consumption in heavy drinking smokers (McKee et al., 2009; Fucito et al., 2011; Mitchell et al., 2012), uncovering the mechanism of action of varenicline could lead to more refined nAChR partial agonists for the treatment of alcoholism. In mice, systemic injection of lower doses of varenicline immediately prior to ethanol bottle presentation reduces ethanol consumption in the DID paradigm (Hendrickson et al., 2010). In addition, this effect of varenicline is reduced in $\alpha 4 \mathrm{KO}$ mice and enhanced in mice that express $\alpha 4^{*}$ $\mathrm{nAChR}$ that are hypersensitive to agonist indicating that activation of $\alpha 4^{*} \mathrm{nAChR}$ may underlie varenicline effects on binge drinking. However, while varenicline was designed to be selective for $\alpha 4 \beta 2^{*}$ $\mathrm{nAChRs}$ at low doses, at high concentrations, varenicline is also a partial agonist at $\alpha 6 \beta 2 *$ nAChRs, a full agonist at $\alpha 3 \beta 4$ and $\alpha 7$ nAChRs, as well as at 5- $\mathrm{HT}_{3}$ receptors (Mihalak et al., 2006; Papke et al., 2010; Lummis et al., 2011; Bordia et al., 2012), which may also explain some of its effects on ethanol consumption especially in response to high doses used to reduce ethanol preference and seeking in most studies using the two-bottle choice $24 \mathrm{~h}$ access paradigm of ethanol consumption. Indeed, varenicline still reduces ethanol consumption in $\beta 2$ and $\alpha 7$ KO mice (Kamens et al., 2010). Varenicline also reduces ethanol consumption in the DID paradigm in $\alpha 5 \mathrm{KO}$ mice (Santos et al., 2012). Thus, the mechanism of varenicline induced reduction in ethanol consumption and the nAChR subtype responsible for this effect is still unclear. However, acutely, varenicline reduces ethanol-mediated DA release in NAc of rats, an effect that diminishes with repeated exposure of the partial agonist (Ericson et al., 2009), consistent with varenicline reducing the rewarding properties of ethanol. In contrast, a recent clinical study found that varenicline potentiated aversion to ethanol in social drinkers (Childs et al., 2012), suggesting the agonist may reduce consumption through an anti-reward pathway.

In addition to varenicline, pre-clinical data are emerging regarding other $\mathrm{nAChR}$ ligands that may prove effective in reducing ethanol consumption. Sazetidine-A, an $\alpha 4 \beta 2^{*}$ nAChRselective "desensitizer" and partial agonist can reduces ethanol consumption in rats (Rezvani et al., 2010). Lobeline, an antagonist with high affinity for $\alpha 4 \beta 2^{*}$ and $\alpha 3 \beta 2^{*}$ nAChRs reduces ethanol consumption in mice in the DID and two-bottle choice paradigm (Farook et al., 2009b). Cytisine, a partial agonist that preferentially activates high affinity $\beta 2^{*}$ nAChRs at low doses but also is a full $\beta 4^{*} \mathrm{nAChR}$ agonist at high doses also reduces ethanol consumption (Bell et al., 2009; Hendrickson et al., 2009; Sajja and Rahman, 2011, 2012). Both lobeline and cytisine reduced ethanolmediated DA release in ventral striatum of mice consistent with blocking of ethanol reward/reinforcement (Sajja et al., 2010). In addition, lobeline and cytisine also reduce the increase in alcohol consumption that occurs with chronic nicotine exposure in the DID paradigm (Sajja and Rahman, 2012). Finally, novel partial agonists targeting $\alpha 3 \beta 4^{*}$ nAChRs reduce ethanol consumption and seeking in rats (Chatterjee et al., 2011).

\section{NEURONAL nAChR SUBUNIT GENES AND ALCOHOL: HUMAN GENETIC ASSOCIATION STUDIES}

There is growing evidence that suggests that common genes may influence the development of alcohol and nicotine behaviors individually as well as contribute to both disorders in humans (True et al., 1999; Bierut et al., 2000; Madden and Heath, 2002). Using twin studies, it was determined that identical twins are two times as likely to be dependent on alcohol and/or nicotine if the other twin is dependent, compared to fraternal twins (Heath et al., 1997).

Recent genome wide association studies have identified several polymorphisms within genetic loci that includes the nAChR subunit genes CHRNA5/A3/B4 (which encode the nAChR $\alpha 5$, $\alpha 3, \beta 4$ subunit, respectively), that are associated with nicotine dependence, COPD, and lung cancer (Amos et al., 2008; Berrettini et al., 2008; Bierut et al., 2008; Hung et al., 2008; Saccone et al., 2010). Interestingly, genetic variation in these genes has also been associated with age of initiation of smoking and alcohol use and level of response of alcohol use (Joslyn et al., 2008; Schlaepfer et al., 2008). Two SNPs associated with nicotine dependence and lung cancer have been found to also be associated with a low level of response to alcohol, a phenotype considered a risk factor for 
likelihood of developing an AUD (Joslyn et al., 2008). Thus, common SNPs may confer susceptibility to both nicotine dependence and alcoholism. In addition, genetic variation in CHRNA5, distinct from those associated with nicotine dependence, are also associated with alcohol dependence (Wang et al., 2009). The mechanistic bases for how polymorphisms in CHRNA5/A3/B4 modulate nicotine and alcohol phenotypes are unclear although distinct SNPs in CHRNA5 have been shown to affect $\alpha 4 \beta 2 \mathrm{nAChR}$ function in vitro and mRNA expression in human brain (Bierut et al., 2008; Wang et al., 2009). It is also unclear if genetic variation in CHRNA5/A3/B4 is specific for modulation of nicotine and alcohol dependence as SNPs are also associated with cocaine and opioid dependence, as well as substance use initiation (Grucza et al., 2008; Sherva et al., 2010; Lubke et al., 2012; but see Chen et al., 2012). Thus, SNPs in this region may affect aspects of addiction common to all drugs of abuse, such as reward, tolerance, or withdrawal. Alternatively, CHRNA5/A3/B4 may play a role in general risk taking behavior or impulsivity which may significantly predispose one to drug addiction (Stephens et al., 2012).

Additional genes encoding $\mathrm{nAChR}$ subunits have been linked to alcohol phenotype. SNPs in CHRNB2, have been associated with the subjective responses to both alcohol and nicotine (Ehringer et al., 2007); whereas only a modest association of alcohol responses with CHRNA4 SNPs were reported. An additional study identified a CHRNA4 SNP associated with alcoholism in a small Korean population (Kim et al., 2004). Finally, SNPs within CHRNA6 and CHRNB3 are associated with heavy alcohol consumption (Hoft et al., 2009; Landgren et al., 2009), as well as smoking behavior (Thorgeirsson et al., 2010).

Together these human genetic studies indicate that heritable polymorphisms within $\mathrm{nAChR}$ subunit genes may predispose distinct populations to increased risk for AUDs and, perhaps nicotine and alcohol co-dependence.

\section{FUTURE DIRECTIONS}

Emerging evidence indicates that SNPs within genes encoding nAChR subunits are associated with alcohol dependence phenotypes. Additional research is needed to understand how SNPs in these subunits modulate the effects of ethanol on nAChRs directly and in animal models of ethanol dependence. It will also be critical to expand the focus of nAChRs and ethanol effects on circuits outside of the mesocorticolimbic pathway. Indeed, recent data indicate that nicotine intake is controlled by the habenulopeduncular axis. This circuit consists of a small, epithalamic structure, the habenula $(\mathrm{Hb})$ which can be divided into medial $(\mathrm{MH})$ and lateral (LH) sub-regions (Hikosaka, 2010). The Hb projects

\section{REFERENCES}

Aistrup, G. L., Marszalec, W., and Narahashi, T. (1999). Ethanol modulation of nicotinic acetylcholine receptor currents in cultured cortical neurons. Mol. Pharmacol. 55, 39-49.

Albuquerque, E. X., Pereira, E. F., Alkondon, M., and Rogers, S. W. (2009). Mammalian nicotinic acetylcholine receptors: from structure to function. Physiol. Rev. 89, 73-120.
Alen, F., Gomez, R., Gonzalez-Cuevas, G., Navarro, M., and Lopez-Moreno, J. A. (2009). Nicotine causes opposite effects on alcohol intake: evidence in an animal experimental model of abstinence and relapse from alcohol. Nicotine Tob. Res. 11, 1304-1311.

Amos, C. I., Wu, X., Broderick, P. I., Gorlov, P., Gu, J., Eisen, T., et al. (2008). Genome-wide association scan of tag SNPs identifies a

to its target brain regions through a conspicuous bundle of axons that make up the fasciculus retroflexus. The LH projects to the rostromedial tegmental nucleus that is involved in the modulation of DA release from the susbstantia nigra pars compacta and VTA (Kaufling et al., 2009; Bromberg-Martin et al., 2010a,b; BalcitaPedicino et al., 2011; Hong et al., 2011; Lecca et al., 2011). The $\mathrm{MH}$ projects to the interpeduncular nucleus (IPN) which, in turn, projects to the median and dorsal raphe nuclei in addition to other brain regions (Figure 2A) (Morley, 1986). Recent data indicate that expression of $\mathrm{nAChRs}$ containing the $\alpha 5$ and/or $\beta 4$ subunits within the $\mathrm{MH}$ control nicotine intake such that genetic deletion of $\alpha 5 \mathrm{nAChRs}$ increases acute intake; whereas overexpression of the $\beta 4 \mathrm{nAChR}$ subunit reduces intake and increases sensitivity to nicotine's aversive properties (Fowler et al., 2011; Frahm et al., 2011). Thus, while the mesocorticolimbic pathway confers acute nicotine reward/reinforcement, the MH-IPN pathway may signal nicotine aversion (but see Laviolette et al., 2008). In addition, the $\mathrm{Hb}-\mathrm{IPN}$ is a critical circuit for the expression of physical signs of nicotine withdrawal (Salas et al., 2009). Because (1) SNPs in nAChR subunit genes CHRNA3/A5/B4 are associated with alcohol dependence phenotypes, (2) these genes are robustly expressed in the Hb-IPN circuitry, and (3) $\alpha 3 \beta 4$ ligands modulate ethanol consumption in rodent models, future studies should explore the role of MH-IPN nAChRs in ethanol consumption and withdrawal behaviors.

\section{SUMMARY}

Neuronal nAChR represent novel therapeutic targets to not only treat nicotine dependence, but also alcohol dependence. The reinforcing properties of acute ethanol, are mediated, in part, by $\alpha 4^{*}$ nAChRs, likely expressed in DAergic neurons of the mesocorticolimbic pathway. Ethanol potentiates the response of high affinity heteromeric nAChRs to both ACh and nicotine. Thus, if ethanol increases ACh release in the VTA, DAergic neurons will be activated via $\mathrm{nAChRs}$ and ethanol will further potentiate this effect (Figure 2B). Chronic nicotine may upregulate these receptors and increase the reinforcing properties of ethanol. Future studies should focus on identifying additional nAChR subunits critical for ethanol effects within and outside the mesocorticolimbic circuitry.

\section{ACKNOWLEDGMENTS}

This study was supported by the National Institute on Alcohol Abuse and Alcoholism award number R01AA017656 (Andrew R. Tapper) and F31AA018915 (Linzy M. Hendrickson). The content is solely the responsibility of the authors and does not necessarily represent the official views of the National Institutes of Health.

susceptibility locus for lung cancer at 15q25.1. Nat. Genet. 40, 616-622.

Anton, R. F., Oroszi, G., O’Malley, S., Couper, D., Swift, R., Pettinati, H., et al. (2008). An evaluation of muopioid receptor (OPRM1) as a predictor of naltrexone response in the treatment of alcohol dependence: results from the combined pharmacotherapies and behavioral interventions for alcohol dependence
(COMBINE) study. Arch. Gen. Psychiatry 65, 135-144.

Baddick, C. G., and Marks, M. J. (2011). An autoradiographic survey of mouse brain nicotinic acetylcholine receptors defined by null mutants. Biochem. Pharmacol. 82, 828-841.

Balcita-Pedicino, J. J., Omelchenko, N., Bell, R., and Sesack, S. R. (2011). The inhibitory influence of the lateral habenula on midbrain 
dopamine cells: ultrastructural evidence for indirect mediation via the rostromedial mesopontine tegmental nucleus. J. Comp. Neurol. 519, 1143-1164.

Bell, R. L., Eiler, B. J. II, Cook, J. B., and Rahman, S. (2009). Nicotinic receptor ligands reduce ethanol intake by high alcohol-drinking HAD-2 rats. Alcohol 43, 581-592.

Benwell, M. E., and Balfour, D. J. (1992). The effects of acute and repeated nicotine treatment on nucleus accumbens dopamine and locomotor activity. Br. J. Pharmacol. 105, 849-856.

Berrettini, W., Yuan, X., Tozzi, F., Song, K., Francks, C., Chilcoat, H., et al. (2008). Alpha-5/alpha-3 nicotinic receptor subunit alleles increase risk for heavy smoking. Mol. Psychiatry $13,368-373$.

Bhutada, P., Mundhada, Y., Ghodki, Y., Dixit, P., Umathe, S., and Jain, K. (2012). Acquisition, expression, and reinstatement of ethanolinduced conditioned place preference in mice: effects of exposure to stress and modulation by mecamylamine. J. Psychopharmacol. 26, 315-323.

Bierut, L. J., Schuckit, M. A., Hesselbrock, V., and Reich, T. (2000). Cooccurring risk factors for alcohol dependence and habitual smoking. Alcohol Res. Health 24, 233-241.

Bierut, L. J., Stitzel, J. A., Wang, J. C., Hinrichs, A. L., Grucza, R. A., Xuei, X., et al. (2008). Variants in nicotinic receptors and risk for nicotine dependence. Am. J. Psychiatry 165, 1163-1171.

Bito-Onon, J. J., Simms, J. A., Chatterjee, S., Holgate, J., and Bartlett, S. E. (2011). Varenicline, a partial agonist at neuronal nicotinic acetylcholine receptors, reduces nicotine-induced increases in $20 \%$ ethanol operant self-administration in Sprague-Dawley rats. Addict. Biol. $16,440-449$.

Blomqvist, O., Engel, J. A., Nissbrandt, H., and Soderpalm, B. (1993). The mesolimbic dopamineactivating properties of ethanol are antagonized by mecamylamine. Eur. J. Pharmacol. 249, 207-213.

Blomqvist, O., Ericson, M., Engel, J. A., and Soderpalm, B. (1997). Accumbal dopamine overflow after ethanol: localization of the antagonizing effect of mecamylamine. Eur. J. Pharmacol. 334, 149-156.

Blomqvist, O., Ericson, M., Johnson, D. H., Engel, J. A., and Soderpalm, B. (1996). Voluntary ethanol intake in the rat: effects of nicotinic acetylcholine receptor blockade or subchronic nicotine treatment. Eur. J. Pharmacol. 314, 257-267.

Blomqvist, O., Soderpalm, B., and Engel, J. A. (1992). Ethanol-induced locomotor activity: involvement of central nicotinic acetylcholine receptors? Brain Res. Bull. 29, 173-178.

Bobo, J. K. (1992). Nicotine dependence and alcoholism epidemiology and treatment. J. Psychoactive Drugs 24, 123-129.

Bobo, J. K., and Husten, C. (2000). Sociocultural influences on smoking and drinking. Alcohol Res. Health 24, 225-232.

Bordia, T., Hrachova, M., Chin, M., McIntosh, J. M., and Quik, M. (2012). Varenicline is a potent partial agonist at $\alpha 6 \beta 2 *$ nicotinic acetylcholine receptors in rat and monkey striatum. J. Pharmacol. Exp. Ther. 342, 327-334.

Borghese, C. M., Ali, D. N., Bleck, V., and Harris, R. A. (2002). Acetylcholine and alcohol sensitivity of neuronal nicotinic acetylcholine receptors: mutations in transmembrane domains. Alcohol. Clin. Exp. Res. 26, 1764-1772.

Borghese, C. M., Henderson, L. A., Bleck, V., Trudell, J. R., and Harris, R. A. (2003a). Sites of excitatory and inhibitory actions of alcohols on neuronal alpha2beta4 nicotinic acetylcholine receptors. J. Pharmacol. Exp. Ther. 307, 42-52.

Borghese, C. M., Wang, L., Bleck, V., and Harris, R. A. (2003b). Mutation in neuronal nicotinic acetylcholine receptors expressed in Xenopus oocytes blocks ethanol action. Addict. Biol. 8, 313-318.

Bromberg-Martin, E. S., Matsumoto, M., Nakahara, H., and Hikosaka, O. (2010a). Multiple timescales of memory in lateral habenula and dopamine neurons. Neuron 67, 499-510.

Bromberg-Martin, E. S., Matsumoto, M., and Hikosaka, O. (2010b). Distinct tonic and phasic anticipatory activity in lateral habenula and dopamine neurons. Neuron 67, 144-155.

Buisson, B., and Bertrand, D. (2001). Chronic exposure to nicotine upregulates the human (alpha)4((beta)2 nicotinic acetylcholine receptor function. J. Neurosci. 21, 1819-1829.

Cardoso, R. A., Brozowski, S. J., ChavezNoriega, L. E., Harpold, M., Valenzuela, C. F., and Harris, R. A. (1999). Effects of ethanol on recombinant human neuronal nicotinic acetylcholine receptors expressed in Xenopus oocytes. J. Pharmacol. Exp. Ther. 289, 774-780.
Carnicella, S., He, D. Y., Yowell, Q. V., Glick, S. D., and Ron, D. (2010). Noribogaine, but not 18MC, exhibits similar actions as ibogaine on GDNF expression and ethanol self-administration. Addict. Biol. 15, 424-433.

Carr, D. B., and Sesack, S. R. (2000). GABA-containing neurons in the rat ventral tegmental area project to the prefrontal cortex. Synapse 38, 114-123.

Cartier, G. E., Yoshikami, D., Gray, W. R., Luo, S., Olivera, B. M., and McIntosh, J. M. (1996). A new alphaconotoxin which targets alpha3beta2 nicotinic acetylcholine receptors. $J$. Biol. Chem. 271, 7522-7528.

CASA. (2000). CASA's cost of living adjustment, using the Bureau of Labor Statistics Inflation Calculator, of 1998 data by Harwood, H. Updating Estimates of the Economic Costs of Alcohol Abuse in the United States: Estimates, Update Methods, and Data. Report prepared by The Lewin Group for the National Institute on Alcohol Abuse and Alcoholism, 2000. Based on estimates, analyses, and data reported in Harwood, H., Fountain, D., and Livermore, G. (1992). The Economic Costs of Alcohol and Drug Abuse in the United States. Report prepared for the National Institute on Drug Abuse and the National Institute on Alcohol Abuse and Alcoholism National Institutes of Health, U.S. Department of Health and Human Services. NIH Publication No 98-4327. Rockville, MD. (2005).

Champtiaux, N., Han, Z. Y., Bessis, A., Rossi, F. M., Zoli, M., Marubio, L., et al. (2002). Distribution and pharmacology of alpha 6-containing nicotinic acetylcholine receptors analyzed with mutant mice. J. Neurosci. 22, 1208-1217.

Changeux, J. P., and Edelstein, S. J. (1998). Allosteric receptors after 30 years. Neuron 21, 959-980.

Chatterjee, S., Steensland, P., Simms, J. A., Holgate, J., Coe, J. W., Hurst, R. S., et al. (2011). Partial agonists of the alpha3beta $4^{*}$ neuronal nicotinic acetylcholine receptor reduce ethanol consumption and seeking in rats. Neuropsychopharmacology 36, 603-615.

Chen, L. S., Xian, H., Grucza, R. A., Saccone, N. L., Wang, J. C., Johnson, E. O., et al. (2012). Nicotine dependence and comorbid psychiatric disorders: examination of specific genetic variants in the CHRNA5A3-B4 nicotinic receptor genes. Drug Alcohol Depend. 123(Suppl. 1), S42-51.
Chi, H., and de Wit, H. (2003). Mecamylamine attenuates the subjective stimulant-like effects of alcohol in social drinkers. Alcohol. Clin. Exp. Res. 27, 780-786.

Childs, E., Roche, D. J., King, A. C. and de Wit, H. (2012). Varenicline potentiates alcohol-induced negative subjective responses and offsets impaired eye movements. Alcohol. Clin. Exp. Res. 36, 906-914.

Christensen, J. K., Moller, I. W., Ronsted, P., and Johansson, B. (1991) Dose-effect relationship of disulfiram in human volunteers. I: clinical studies. Pharmacol. Toxicol. 68, 163-165.

Clark, A., Lindgren, S., Brooks, S. P., Watson, W. P., and Little, H. J. (2001). Chronic infusion of nicotine can increase operant self-administration of alcohol. Neuropharmacology 41 , 108-117.

Clark, A., and Little, H. J. (2004). Interactions between low concentrations of ethanol and nicotine on firing rate of ventral tegmental dopamine neurones. Drug Alcohol Depend. 75, 199-206.

Coe, J. W., Brooks, P. R., Vetelino, M. G., Wirtz, M. C., Arnold, E. P., Huang, J., et al. (2005). Varenicline: an alpha4beta2 nicotinic receptor partial agonist for smoking cessation. $J$. Med. Chem. 48, 3474-3477.

Cornwall, J., Cooper, J. D., and Phillipson, O. T. (1990). Afferent and efferent connections of the laterodorsal tegmental nucleus in the rat. Brain Res. Bull. 25, 271-284.

Corrigall, W. A., and Coen, K. M. (1991). Selective dopamine antagonists reduce nicotine self-administration. Psychopharmacology (Berl.) 104, 171-176.

Corrigall, W. A., Coen, K. M., and Adamson, K. L. (1994). Selfadministered nicotine activates the mesolimbic dopamine system through the ventral tegmental area. Brain Res. 653, 278-284.

Corrigall, W. A., Franklin, K. B., Coen, K. M., and Clarke, P. B. (1992) The mesolimbic dopaminergic system is implicated in the reinforcing effects of nicotine. Psychopharmacology (Berl.) 107, 285-259.

Corringer, P. J., Le Novere, N., and Changeux, J. P. (2000). Nicotinic receptors at the amino acid level. Annu. Rev. Pharmacol. Toxicol. 40, 431-458.

Damaj, M. I. (2001). Influence of gender and sex hormones on nicotine acute pharmacological effects in mice. $J$. Pharmacol. Exp. Ther. 296, 132-140.

Dani, J. A., and Bertrand, D. (2007). Nicotinic acetylcholine receptors 
and nicotinic cholinergic mechanisms of the central nervous system. Annu. Rev. Pharmacol. Toxicol. 47, 699-729.

De Biasi, M., and Dani, J. A. (2011). Reward, addiction, withdrawal to nicotine. Annu. Rev. Neurosci. 34, 105-130.

Di Chiara, G., and Imperato, A. (1988). Drugs abused by humans preferentially increase synaptic dopamine concentrations in the mesolimbic system of freely moving rats. Proc. Natl. Acad. Sci. U.S.A. 85, 5274-5278.

Diana, M., Rossetti, Z. L., and Gessa, G. (1993). Rewarding and aversive effects of ethanol: interplay of GABA, glutamate and dopamine. Alcohol. Alcohol Suppl. 2, 315-319.

DiFranza, J. R., and Guerrera, M. P. (1990). Alcoholism and smoking. J. Stud. Alcohol 51, 130-135.

Ding, Z. M., Katner, S. N., Rodd, Z. A., Truitt, W., Hauser, S. R., Deehan, G. A. Jr., et al. (2012). Repeated exposure of the posterior ventral tegmental area to nicotine increases the sensitivity of local dopamine neurons to the stimulating effects of ethanol. Alcohol 46, 217-223.

Dopico, A. M., and Lovinger, D. M. (2009). Acute alcohol action and desensitization of ligand-gated ion channels. Pharmacol. Rev. 61, 98-114.

Dowell, C., Olivera, B. M., Garrett, J. E., Staheli, S. T., Watkins, M., Kuryatov, A., et al. (2003). Alphaconotoxin PIA is selective for alpha6 subunit-containing nicotinic acetylcholine receptors. J. Neurosci. 23, 8445-8452.

Drago, J., McColl, C. D., Horne, M. K., Finkelstein, D. I., and Ross, S. A. (2003). Neuronal nicotinic receptors: insights gained from gene knockout and knockin mutant mice. Cell. Mol. Life Sci. 60, 1267-1280.

Dyr, W., Koros, E., Bienkowski, P., and Kostowski, W. (1999). Involvement of nicotinic acetylcholine receptors in the regulation of alcohol drinking in Wistar rats. Alcohol Alcohol. 34, 43-47.

Ehringer, M. A., Clegg, H. V., Collins, A. C., Corley, R. P., Crowley, T., Hewitt, J. K., et al. (2007). Association of the neuronal nicotinic receptor beta2 subunit gene (CHRNB2) with subjective responses to alcohol and nicotine. Am. J. Med. Genet. B Neuropsychiatr. Genet. 144B, 596-604.

Ericson, M., Blomqvist, O., Engel, J. A., and Soderpalm, B. (1998). Voluntary ethanol intake in the rat and the associated accumbal dopamine overflow are blocked by ventral tegmental mecamylamine. Eur. J. Pharmacol. 358, 189-196.

Ericson, M., Engel, J. A., and Soderpalm, B. (2000). Peripheral involvement in nicotine-induced enhancement of ethanol intake. Alcohol 21, 37-47.

Ericson, M., Lof, E., Stomberg, R., and Soderpalm, B. (2009). The smoking cessation medication varenicline attenuates alcohol and nicotine interactions in the rat mesolimbic dopamine system. J. Pharmacol. Exp. Ther. 329, 225-230.

Ericson, M., Molander, A., Lof, E., Engel, J. A., and Soderpalm, B. (2003). Ethanol elevates accumbal dopamine levels via indirect activation of ventral tegmental nicotinic acetylcholine receptors. Eur. J. Pharmacol. 467, 85-93.

Exley, R., Maubourguet, N., David, V., Eddine, R., Evrard, A., Pons, S., et al. (2011). Distinct contributions of nicotinic acetylcholine receptor subunit alpha4 and subunit alpha6 to the reinforcing effects of nicotine. Proc. Natl. Acad. Sci. U.S.A. 108, 7577-7582.

Fallon, J. H., Schmued, L. C., Wang, C., Miller, R., and Banales, G. (1984). Neurons in the ventral tegmentum have separate populations projecting to telencephalon and inferior olive, are histochemically different, and may receive direct visual input. Brain Res. 321, 332-336.

Farook, J. M., Lewis, B., Gaddis, J. G., Littleton, J. M., and Barron, S. (2009a). Effects of mecamylamine on alcohol consumption and preference in male C57BL/6J mice. Pharmacology 83, 379-384.

Farook, J. M., Lewis, B., Gaddis, J. G., Littleton, J. M., and Barron, S. (2009b). Lobeline, a nicotinic partial agonist attenuates alcohol consumption and preference in male C57BL/6J mice. Physiol. Behav. 97, 503-506.

Fields, H. L., Hjelmstad, G. O., Margolis, E. B., and Nicola, S. M. (2007). Ventral tegmental area neurons in learned appetitive behavior and positive reinforcement. Annu. Rev. Neurosci. 30, 289-316.

Foddai, M., Dosia, G., Spiga, S., and Diana, M. (2004). Acetaldehyde increases dopaminergic neuronal activity in the VTA. Neuropsychopharmacology 29, 530-536.

Fonck, C., Cohen, B. N., Nashmi, R., Whiteaker, P., Wagenaar, D. A., Rodrigues-Pinguet, N., et al. (2005). Novel seizure phenotype and sleep disruptions in knock-in mice with hypersensitive alpha $4^{*}$ nicotinic receptors. J. Neurosci. 25, 11396-11411.
Forman, S. A., and Zhou, Q. (1999). Novel modulation of a nicotinic receptor channel mutant reveals that the open state is stabilized by ethanol. Mol. Pharmacol. 55, 102-108.

Fowler, C. D., Lu, Q., Johnson, P. M., Marks, M. J., and Kenny, P. J. (2011). Habenular alpha5 nicotinic receptor subunit signalling controls nicotine intake. Nature 471, 597-601.

Frahm, S., Slimak, M. A., Ferrarese, L., Santos-Torres, J., Antolin-Fontes, B., Auer, S., et al. (2011). Aversion to nicotine is regulated by the balanced activity of beta 4 and alpha 5 nicotinic receptor subunits in the medial habenula. Neuron 70, 522-535.

Fucito, L. M., Toll, B. A., Wu, R., Romano, D. M., Tek, E., and O'Malley, S. S. (2011). A preliminary investigation of varenicline for heavy drinking smokers. Psychopharmacology (Berl.) 215, 655-663.

Funk, D., Marinelli, P. W., and Le, A. D. (2006). Biological processes underlying co-use of alcohol and nicotine: neuronal mechanisms, crosstolerance, and genetic factors. Alcohol Res. Health 29, 186-192.

Gatto, G. J., McBride, W. J., Murphy, J. M., Lumeng, L., and Li, T. K. (1994). Ethanol self-infusion into the ventral tegmental area by alcohol-preferring rats. Alcohol 11, 557-564.

Geisler, S., and Zahm, D. S. (2005) Afferents of the ventral tegmental area in the rat-anatomical substratum for integrative functions. $J$. Comp. Neurol. 490, 270-294.

George, D. T., Gilman, J., Hersh, J., Thorsell, A., Herion, D., Geyer, C. et al. (2008). Neurokinin 1 receptor antagonism as a possible therapy for alcoholism. Science 319, 1536-1539.

Gessa, G. L., Muntoni, F., Collu, M., Vargiu, L., and Mereu, G. (1985). Low doses of ethanol activate dopaminergic neurons in the ventral tegmental area. Brain Res. 348, 201-203.

Gonzales, D., Rennard, S. I., Nides, M., Oncken, C., Azoulay, S., Billing, C. B., et al. (2006). Varenicline, an alpha4beta2 nicotinic acetylcholine receptor partial agonist, vs sustained-release bupropion and placebo for smoking cessation: a randomized controlled trial. JAMA 296, 47-55.

Gotti, C., Guiducci, S., Tedesco, V., Corbioli, S., Zanetti, L., Moretti, M., et al. (2010). Nicotinic acetylcholine receptors in the mesolimbic pathway: primary role of ventral tegmental area alpha6beta2* receptors in mediating systemic nicotine effects on dopamine release, locomotion, and reinforcement. J. Neurosci. 30, 5311-5325.

Gotti, C., Moretti, M., Gaimarri, A., Zanardi, A., Clementi, F., and Zoli, M. (2007). Heterogeneity and complexity of native brain nicotinic receptors. Biochem. Pharmacol. 74, 1102-1111.

Grady, S. R., Salminen, O., Laverty, D. C., Whiteaker, P., McIntosh, J. M., Collins, A. C., et al. (2007). The subtypes of nicotinic acetylcholine receptors on dopaminergic terminals of mouse striatum. Biochem. Pharmacol. 74, 1235-1246.

Grant, B. F., Hasin, D. S., Chou, S. P., Stinson, F. S., and Dawson, D. A. (2004). Nicotine dependence and psychiatric disorders in the United States: results from the national epidemiologic survey on alcohol and related conditions. Arch. Gen. Psychiatry 61, 1107-1115.

Grucza, R. A., Wang, J. C., Stitzel, J. A., Hinrichs, A. L., Saccone, S. F., Saccone, N. L., et al. (2008). A risk allele for nicotine dependence in CHRNA5 is a protective allele for cocaine dependence. Biol. Psychiatry 64, 922-929.

Guan, Y., Xiao, C., Krnjevic, K., Xie, G., Zuo, W., and Ye, J. H. (2012). GABAergic actions mediate opposite ethanol effects on dopaminergic neurons in the anterior and posterior ventral tegmental area. J. Pharmacol. Exp. Ther. 341, 33-42.

Harvey, S. C., and Luetje, C. W. (1996). Determinants of competitive antagonist sensitivity on neuronal nicotinic receptor beta subunits. J. Neurosci. 16, 3798-3806.

Harvey, S. C., Maddox, F. N., and Luetje, C. W. (1996). Multiple determinants of dihydro-beta-erythroidine sensitivity on rat neuronal nicotinic receptor alpha subunits. J. Neurochem. 67, 1953-1959.

Hauser, S. R., Getachew, B., Oster, S. M., Dhaher, R., Ding, Z. M., Bell, R. L., et al. (2012). Nicotine modulates alcohol-seeking and relapse by alcohol-preferring $(\mathrm{P})$ rats in a timedependent manner. Alcohol. Clin. Exp. Res. 36, 43-54.

Heath, A. C., Bucholz, K. K., Madden, P. A., Dinwiddie, S. H., Slutske, W. S., Bierut, L. J., et al. (1997). Genetic and environmental contributions to alcohol dependence risk in a national twin sample: consistency of findings in women and men. Psychol. Med. 27, 1381-1396.

Hendrickson, L. M., Gardner, P., and Tapper, A. R. (2011). Nicotinic acetylcholine receptors containing 
the alpha4 subunit are critical for the nicotine-induced reduction of acute voluntary ethanol consumption. Channels (Austin) 5, 124-127.

Hendrickson, L. M., Zhao-Shea, R., Pang, X., Gardner, P. D., and Tapper, A. R. (2010). Activation of alpha4* nAChRs is necessary and sufficient for varenicline-induced reduction of alcohol consumption. J. Neurosci. 30, 10169-10176.

Hendrickson, L. M., Zhao-Shea, R., and Tapper, A. R. (2009). Modulation of ethanol drinking-in-thedark by mecamylamine and nicotinic acetylcholine receptor agonists in C57BL/6J mice. Psychopharmacology (Berl.) 204, 563-572.

Herkenham, M., and Nauta, W. J. (1979). Efferent connections of the habenular nuclei in the rat. J. Comp. Neurol. 187, 19-47.

Hikosaka, O. (2010). The habenula: from stress evasion to value-based decision-making. Nat. Rev. Neurosci. 11, 503-513.

Hoft, N. R., Corley, R. P., McQueen, M. B., Huizinga, D., Menard, S., and Ehringer, M. A. (2009). SNPs in CHRNA6 and CHRNB3 are associated with alcohol consumption in a nationally representative sample. Genes Brain Behav. 8, 631-637.

Hong, S., Jhou, T. C., Smith, M., Saleem, K. S., and Hikosaka, O. (2011). Negative reward signals from the lateral habenula to dopamine neurons are mediated by rostromedial tegmental nucleus in primates. J. Neurosci. 31, 11457-11471.

Hung, R. J., McKay, J. D., Gaborieau, V., Boffetta, P., Hashibe, M., Zaridze, D., et al. (2008). A susceptibility locus for lung cancer maps to nicotinic acetylcholine receptor subunit genes on 15q25. Nature 452, 633-637.

Ikemoto, S. (2007). Dopamine reward circuitry: two projection systems from the ventral midbrain to the nucleus accumbens-olfactory tubercle complex. Brain Res. Rev. 56, 27-78.

Ikemoto, S., McBride, W. J., Murphy, J. M., Lumeng, L., and Li, T. K. (1997). 6-OHDA-lesions of the nucleus accumbens disrupt the acquisition but not the maintenance of ethanol consumption in the alcohol-preferring $\mathrm{P}$ line of rats. Alcohol. Clin. Exp. Res. 21, 1042-1046.

Ikemoto, S., Qin, M., and Liu, Z. H. (2006). Primary reinforcing effects of nicotine are triggered from multiple regions both inside and outside the ventral tegmental area. J. Neurosci. 26, 723-730.
Jerlhag, E., Grotli, M., Luthman, K., Svensson, L., and Engel, J. A. (2006). Role of the subunit composition of central nicotinic acetylcholine receptors for the stimulatory and dopamine-enhancing effects of ethanol. Alcohol Alcohol. 41, 486-493.

Ji, H., and Shepard, P. D. (2007). Lateral habenula stimulation inhibits rat midbrain dopamine neurons through a GABA(A) receptormediated mechanism. J. Neurosci. 27, 6923-6930.

Job, M. O., Tang, A., Hall, F. S., Sora, I., Uhl, G. R., Bergeson, S. E., et al. (2007). Mu (mu) opioid receptor regulation of ethanol-induced dopamine response in the ventral striatum: evidence of genotype specific sexual dimorphic epistasis. Biol. Psychiatry 62, 627-634.

Johnson, D. H., Blomqvist, O., Engel, J. A., and Soderpalm, B. (1995). Subchronic intermittent nicotine treatment enhances ethanolinduced locomotor stimulation and dopamine turnover in mice. Behav. Pharmacol. 6, 203-207.

Jorenby, D. E., Hays, J. T., Rigotti, N. A., Azoulay, S., Watsky, E. J., Williams, K. E., et al. (2006). Efficacy of varenicline, an alpha4beta 2 nicotinic acetylcholine receptor partial agonist, vs placebo or sustained-release bupropion for smoking cessation: a randomized controlled trial. JAMA 296, 56-63.

Joslyn, G., Brush, G., Robertson, M., Smith, T. L., Kalmijn, J., Schuckit, M., et al. (2008). Chromosome 15q25.1 genetic markers associated with level of response to alcohol in humans. Proc. Natl. Acad. Sci. U.S.A. 105, 20368-20373.

Kamens, H. M., Andersen, J., and Picciotto, M. R. (2010). Modulation of ethanol consumption by genetic and pharmacological manipulation of nicotinic acetylcholine receptors in mice. Psychopharmacology (Berl.) 208, 613-626.

Kamens, H. M., Hoft, N. R., Cox, R. J., Miyamoto, J. H., and Ehringer, M. A. (2012). The alpha6 nicotinic acetylcholine receptor subunit influences ethanol-induced sedation. Alcohol 46, 463-471.

Kamens, H. M., and Phillips, T. J. (2008). A role for neuronal nicotinic acetylcholine receptors in ethanol-induced stimulation, but not cocaine- or methamphetamineinduced stimulation. Psychopharmacology (Berl.) 196, 377-387.

Karlin, A. (2002). Emerging structure of the nicotinic acetylcholine receptors. Nat. Rev. Neurosci. 3, 102-114.
Kaufling, J., Veinante, P., Pawlowski, S. A., Freund-Mercier, M. J., and Barrot, M. (2009). Afferents to the GABAergic tail of the ventral tegmental area in the rat. J. Comp. Neurol. 513, 597-621.

Kiianmaa, K. (1978). Decreased intoxicating effect of ethanol in rats after 6-hydroxydopamineinduced degeneration of ascending dopamine pathways. Pharmacol. Biochem. Behav. 9, 391-393.

Kim, S. A., Kim, J. W., Song, J. Y., Park, S., Lee, H. J., and Chung, J. H. (2004). Association of polymorphisms in nicotinic acetylcholine receptor alpha 4 subunit gene (CHRNA4), mu-opioid receptor gene (OPRM1), and ethanolmetabolizing enzyme genes with alcoholism in Korean patients. Alcohol 34, 115-120.

Klink, R., de Kerchove d'Exaerde, A., Zoli, M., and Changeux, J. P. (2001). Molecular and physiological diversity of nicotinic acetylcholine receptors in the midbrain dopaminergic nuclei. J. Neurosci. 21, 1452-1463.

Koob, G. F. (1992). Drugs of abuse: anatomy, pharmacology and function of reward pathways. Trends Pharmacol. Sci. 13, 177-184.

Koob, G. F., and Weiss, F. (1990). Pharmacology of drug selfadministration. Alcohol 7, 193-197.

Kuehn, B. M. (2009). Findings on alcohol dependence point to promising avenues for targeted therapies. JAMA 301, 1643-1645.

Kuzmin, A., Jerlhag, E., Liljequist, S., and Engel, J. (2009). Effects of subunit selective nACh receptors on operant ethanol self-administration and relapse-like ethanol-drinking behavior. Psychopharmacology (Berl.) 203, 99-108.

Lanca, A. J. (1994). Reduction of voluntary alcohol intake in the rat by modulation of the dopaminergic mesolimbic system: transplantation of ventral mesencephalic cell suspensions. Neuroscience 58, 359-369.

Landgren, S., Engel, J. A., Andersson, M. E., Gonzalez-Quintela, A., Campos, J., Nilsson, S., et al. (2009). Association of nAChR gene haplotypes with heavy alcohol use and body mass. Brain Res. 1305(Suppl.), S72-9.

Larsson, A., Edstrom, L., Svensson, L. Soderpalm, B., and Engel, J. A. (2005). Voluntary ethanol intake increases extracellular acetylcholine levels in the ventral tegmental area in the rat. Alcohol Alcohol. 40, 349-358.

Larsson, A., Jerlhag, E., Svensson, L., Soderpalm, B., and Engel, J. A.
(2004). Is an alpha-conotoxin MIIsensitive mechanism involved in the neurochemical, stimulatory, and rewarding effects of ethanol? Alcohol 34, 239-250.

Larsson, A., Svensson, L., Soderpalm, B., and Engel, J. A. (2002). Role of different nicotinic acetylcholine receptors in mediating behavioral and neurochemical effects of ethanol in mice. Alcohol 28, 157-167.

Laviolette, S. R., Lauzon, N. M., Bishop, S. F., Sun, N., and Tan, H. (2008) Dopamine signaling through D1like versus D2-like receptors in the nucleus accumbens core versus shell differentially modulates nicotine reward sensitivity. J. Neurosci. 28, 8025-8033.

Le, A. D., Corrigall, W. A., Harding, J. W., Juzytsch, W., and Li, T. K. (2000). Involvement of nicotinic receptors in alcohol self-administration. Alcohol. Clin. Exp. Res. 24, 155-163.

Le, A. D., Wang, A., Harding, S., Juzytsch, W., and Shaham, Y. (2003). Nicotine increases alcohol selfadministration and reinstates alcohol seeking in rats. Psychopharmacology (Berl.) 168, 216-221.

Le Novere, N., and Changeux, J. P. (1995). Molecular evolution of the nicotinic acetylcholine receptor: an example of multigene family in excitable cells. J. Mol. Evol. 40, 155-172.

Lecca, S., Melis, M., Luchicchi, A., Ennas, M. G., Castelli, M. P., Muntoni, A. L., et al. (2011). Effects of drugs of abuse on putative rostromedial tegmental neurons, inhibitory afferents to midbrain dopamine cells. Neuropsychopharmacology 36, 589-602.

Lewis, M. J., and June, H. L. (1990). Neurobehavioral studies of ethanol reward and activation. Alcohol 7, 213-219.

Li, W., Doyon, W. M., and Dani, J. A. (2011). Acute in vivo nicotine administration enhances synchrony among dopamine neurons. Biochem. Pharmacol. 82, 977-983.

Littleton, J., Barron, S., Prendergast, M., and Nixon, S. J. (2007). Smoking kills (alcoholics)! shouldn't we do something about it? Alcohol Alcohol. 42, 167-173.

Liu, L., Hendrickson, L. M., Guildford, M., Zhao-Shea, R., Gardner, P. D., and Tapper, A. R. (2013). Nicotinic acetylcholine receptors containing the alpha4 subunit modulate alcohol reward. Biol. Psychiatry. 73, 738-746.

Liu, L., Zhao-Shea, R., McIntosh, J. M., Gardner, P. D., and Tapper, 
A. R. (2012). Nicotine persistently activates ventral tegmental area dopaminergic neurons via nicotinic acetylcholine receptors containing alpha4 and alpha6 subunits. Mol. Pharmacol. 81, 541-548.

Lof, E., Olausson, P., deBejczy, A., Stomberg, R., McIntosh, J. M., Taylor, J. R., et al. (2007). Nicotinic acetylcholine receptors in the ventral tegmental area mediate the dopamine activating and reinforcing properties of ethanol cues. Psychopharmacology (Berl.) 195, 333-343.

Lopez-Moreno, J. A., Trigo-Diaz, J. M., Rodriguez de Fonseca, F., Gonzalez Cuevas, G., Gomez de Heras, R., Crespo Galan, I., et al. (2004). Nicotine in alcohol deprivation increases alcohol operant self-administration during reinstatement. Neuropharmacology 47, 1036-1044.

Lubke, G. H., Stephens, S. H., Lessem, J. M., Hewitt, J. K., and Ehringer, M. A. (2012). The CHRNA5/A3/B4 gene cluster and tobacco, alcohol, cannabis, inhalants and other substance use initiation: replication and new findings using mixture analyses. Behav. Genet. 42, 636-646.

Lummis, S. C., Thompson, A. J., Bencherif, M., and Lester, $\mathrm{H}$. A. (2011). Varenicline is a potent agonist of the human 5-hydroxytryptamine3 receptor. $J$. Pharmacol. Exp. Ther. 339, 125-131.

Madden, P. A., and Heath, A. C. (2002). Shared genetic vulnerability in alcohol and cigarette use and dependence. Alcohol. Clin. Exp. Res. 26, 1919-1921.

Mansvelder, H. D., Keath, J. R., and McGehee, D. S. (2002). Synaptic mechanisms underlie nicotine-induced excitability of brain reward areas. Neuron 33, 905-919.

Margolis, E. B., Lock, H., Hjelmstad, G. O., and Fields, H. L. (2006a). The ventral tegmental area revisited: is there an electrophysiological marker for dopaminergic neurons? J. Physiol. (Lond.) 577, 907-924.

Margolis, E. B., Lock, H., Chefer, V. I., Shippenberg, T. S., Hjelmstad, G. O., and Fields, H. L. (2006b). Kappa opioids selectively control dopaminergic neurons projecting to the prefrontal cortex. Proc. Natl. Acad. Sci. U.S.A. 103, 2938-2942.

Marszalec, W., Aistrup, G. L., and Narahashi, T. (1999). Ethanol-nicotine interactions at alpha-bungarotoxininsensitive nicotinic acetylcholine receptors in rat cortical neurons. Alcohol. Clin. Exp. Res. 23, 439-445.
Marubio, L. M., Gardier, A. M., Durier, S., David, D., Klink, R., Arroyo-Jimenez, M. M., et al. (2003). Effects of nicotine in the dopaminergic system of mice lacking the alpha4 subunit of neuronal nicotinic acetylcholine receptors. Eur. J. Neurosci. 17, 1329-1337.

Maskos, U., Molles, B. E., Pons, S. Besson, M., Guiard, B. P., Guilloux, J. P., et al. (2005). Nicotine reinforcement and cognition restored by targeted expression of nicotinic receptors. Nature 436, 103-107.

Mason, B. J. (2003). Acamprosate and naltrexone treatment for alcohol dependence: an evidencebased risk-benefits assessment. Eur. Neuropsychopharmacol. 13, 469-475.

Mason, B. J., Goodman, A. M., Chabac, S., and Lehert, P. (2006). Effect of oral acamprosate on abstinence in patients with alcohol dependence in a double-blind, placebo-controlled trial: the role of patient motivation. J. Psychiatr. Res. 40, 383-393.

Matsumoto, M., and Hikosaka, O. (2007). Lateral habenula as a source of negative reward signals in dopamine neurons. Nature 447, 1111-1115.

McGehee, D. S., Heath, M. J., Gelber, S., Devay, P., and Role, L. W. (1995). Nicotine enhancement of fast excitatory synaptic transmission in CNS by presynaptic receptors. Science 269, 1692-1696.

McGehee, D. S., and Role, L. W. (1995). Physiological diversity of nicotinic acetylcholine receptors expressed by vertebrate neurons. Annu. Rev. Physiol. 57, 521-546.

McKee, S. A., Harrison, E. L., O'Malley, S. S., Krishnan-Sarin, S., Shi, J., Tetrault, J. M., et al. (2009). Varenicline reduces alcohol self-administration in heavydrinking smokers. Biol. Psychiatry 66, 185-190.

Mereu, G., Fadda, F., and Gessa, G. L. (1984). Ethanol stimulates the firing rate of nigral dopaminergic neurons in unanesthetized rats. Brain Res. 292, 63-69.

Meyerhoff, D. J., Tizabi, Y., Staley, J. K., Durazzo, T. C., Glass, J. M., and Nixon, S. J. (2006). Smoking comorbidity in alcoholism: neurobiological and neurocognitive consequences. Alcohol. Clin. Exp. Res. 30, 253-264.

Mihalak, K. B., Carroll, F. I., and Luetje, C. W. (2006). Varenicline is a partial agonist at alpha4beta2 and a full agonist at alpha7 neuronal nicotinic receptors. Mol. Pharmacol. 70, 801-805.
Millar, N. S., and Gotti, C. (2009). Diversity of vertebrate nicotinic acetylcholine receptors. Neuropharmacology 56, 237-246.

Miller, N. S., and Gold, M. S. (1998). Comorbid cigarette and alcohol addiction: epidemiology and treatment. J. Addict. Dis. 17, 55-66.

Mitchell, J. M., Teague, C. H., Kayser, A. S., Bartlett, S. E., and Fields, H. L. (2012). Varenicline decreases alcohol consumption in heavydrinking smokers. Psychopharmacology (Berl.) 223, 299-306.

Miyazawa, A., Fujiyoshi, Y., and Unwin, N. (2003). Structure and gating mechanism of the acetylcholine receptor pore. Nature 423, 949-955.

Mogg, A. J., Whiteaker, P., McIntosh, J. M., Marks, M., Collins, A. C., and Wonnacott, S. (2002). Methyllycaconitine is a potent antagonist of alpha-conotoxinMII-sensitive presynaptic nicotinic acetylcholine receptors in rat striatum. J. Pharmacol. Exp. Ther. 302, 197-204.

Mokdad, A. H., Marks, J. S., Stroup, D. F., and Gerberding, J. L. (2004). Actual causes of death in the United States, 2000. JAMA 291, 1238-1245.

Morley, B. J. (1986). The interpeduncular nucleus. Int. Rev. Neurobiol. 28 , 157-182.

Moroni, M., Zwart, R., Sher, E., Cassels, B. K., and Bermudez, I. (2006). alpha4beta2 nicotinic receptors with high and low acetylcholine sensitivity: pharmacology, stoichiometry, and sensitivity to long-term exposure to nicotine. Mol. Pharmacol. 70, 755-768.

Nadal, R., Chappell, A. M., and Samson, H. H. (1998). Effects of nicotine and mecamylamine microinjections into the nucleus accumbens on ethanol and sucrose self-administration. Alcohol. Clin. Exp. Res. 22, 1190-1198.

Nagata, K., Aistrup, G. L., Huang, C. S., Marszalec, W., Song, J. H., Yeh, J. Z., et al. (1996). Potent modulation of neuronal nicotinic acetylcholine receptor-channel by ethanol. Neurosci. Lett. 217, 189-193.

Nashmi, R., Xiao, C., Deshpande, P., McKinney, S., Grady, S. R., Whiteaker, P., et al. (2007). Chronic nicotine cell specifically upregulates functional alpha $4^{*}$ nicotinic receptors: basis for both tolerance in midbrain and enhanced long-term potentiation in perforant path. $J$. Neurosci. 27, 8202-8218.

Nelson, M. E., Kuryatov, A., Choi, C. H., Zhou, Y., and Lindstrom, J.
(2003). Alternate stoichiometries of alpha4beta 2 nicotinic acetylcholine receptors. Mol. Pharmacol. 63, 332-341.

Oakman, S. A., Faris, P. L., Kerr, P. E., Cozzari, C., and Hartman, B. K. (1995). Distribution of pontomesencephalic cholinergic neurons projecting to substantia nigra differs significantly from those projecting to ventral tegmental area. J. Neurosci. 15, 5859-5869.

Okamoto, T., Harnett, M. T., and Morikawa, H. (2006). Hyperpolarization-activated cation current (Ih) is an ethanol target in midbrain dopamine neurons of mice. J. Neurophysiol. 95, 619-626.

Olausson, P., Ericson, M., Lof, E., Engel, J. A., and Soderpalm, B. (2001). Nicotine-induced behavioral disinhibition and ethanol preference correlate after repeated nicotine treatment. Eur. J. Pharmacol. 417, 117-123.

O'Malley, S. S., Jaffe, A. J., Chang, G., Schottenfeld, R. S., Meyer, R. E., and Rounsaville, B. (1992). Naltrexone and coping skills therapy for alcohol dependence. A controlled study. Arch. Gen. Psychiatry 49, 881-887.

Oslin, D. W., Berrettini, W. H., and O’Brien, C. P. (2006). Targeting treatments for alcohol dependence: the pharmacogenetics of naltrexone. Addict. Biol. 11, 397-403.

Papke, R. L., Wecker, L., and Stitzel, J. A. (2010). Activation and inhibition of mouse muscle and neuronal nicotinic acetylcholine receptors expressed in Xenopus oocytes. J. Pharmacol. Exp. Ther. 333, 501-518.

Pettinati, H. M., Anton, R. F., and Willenbring, M. L. (2006). The combine study-: an overview of the largest pharmacotherapy study to date for treating alcohol dependence. Psychiatry (Edgmont) 3, 36-39.

Picciotto, M. R., Zoli, M., Rimondini, R., Lena, C., Marubio, L. M., Pich, E. M., et al. (1998). Acetylcholine receptors containing the beta 2 subunit are involved in the reinforcing properties of nicotine. Nature 391, 173-177.

Pidoplichko, V. I., Noguchi, J., Areola, O. O., Liang, Y., Peterson, J., Zhang, T., et al. (2004). Nicotinic cholinergic synaptic mechanisms in the ventral tegmental area contribute to nicotine addiction. Learn. Mem. 11, 60-69.

Pons, S., Fattore, L., Cossu, G., Tolu, S., Porcu, E., McIntosh, J. M., et al. (2008). Crucial role of alpha4 and alpha6 nicotinic acetylcholine receptor subunits from ventral tegmental area in systemic nicotine 
self-administration. J. Neurosci. 28, 12318-12327.

Pontieri, F. E., Tanda, G., Orzi, F., and Di Chiara, G. (1996). Effects of nicotine on the nucleus accumbens and similarity to those of addictive drugs. Nature 382, 255-257.

Potthoff, A. D., Ellison, G., and Nelson, L. (1983). Ethanol intake increases during continuous administration of amphetamine and nicotine, but not several other drugs. Pharmacol. Biochem. Behav. 18, 489-493.

Rassnick, S., Stinus, L., and Koob, G. F. (1993). The effects of 6hydroxydopamine lesions of the nucleus accumbens and the mesolimbic dopamine system on oral self-administration of ethanol in the rat. Brain Res. 623, 16-24.

Rezvani, A. H., Overstreet, D. H., Yang, Y., Maisonneuve, I. M., Bandarage, U. K., Kuehne, M. E., et al. (1997). Attenuation of alcohol consumption by a novel nontoxic ibogaine analogue (18-methoxycoronaridine) in alcohol-preferring rats. Pharmacol. Biochem. Behav. 58, 615-619.

Rezvani, A. H., Slade, S., Wells, C., Petro, A., Lumeng, L., Li, T. K., et al. (2010). Effects of sazetidine-A, a selective alpha4beta2 nicotinic acetylcholine receptor desensitizing agent on alcohol and nicotine self-administration in selectively bred alcohol-preferring (P) rats. Psychopharmacology (Berl.) 211, 161-174.

Rhodes, J. S., Best, K., Belknap, J. K., Finn, D. A., and Crabbe, J. C. (2005). Evaluation of a simple model of ethanol drinking to intoxication in C57BL/6J mice. Physiol. Behav. 84, 53-63.

Rhodes, J. S., Ford, M. M., Yu, C. H., Brown, L. L., Finn, D. A., Garland, T. Jr., et al. (2007). Mouse inbred strain differences in ethanol drinking to intoxication. Genes Brain Behav. 6, 1-18.

Rodd, Z. A., Bell, R. L., Melendez, R. I., Kuc, K. A., Lumeng, L., Li, T. K., et al. (2004a). Comparison of intracranial self-administration of ethanol within the posterior ventral tegmental area between alcohol-preferring and Wistar rats. Alcohol. Clin. Exp. Res. 28, 1212-1219.

Rodd, Z. A., Melendez, R. I., Bell, R. L., Kuc, K. A., Zhang, Y., Murphy, J. M., et al. (2004b). Intracranial selfadministration of ethanol within the ventral tegmental area of male Wistar rats: evidence for involvement of dopamine neurons. J. Neurosci. 24, 1050-1057.

Rodd, Z. A., Bell, R. L., Oster, S. M., Toalston, J. E., Pommer,
T. J., McBride, W. J., et al. (2010). Serotonin-3 receptors in the posterior ventral tegmental area regulate ethanol self-administration of alcohol-preferring (P) rats. Alcohol $44,245-255$.

Role, L. W., and Berg, D. K. (1996). Nicotinic receptors in the development and modulation of CNS synapses. Neuron 16, 1077-1085.

Room, R. (2004). Smoking and drinking as complementary behaviours. Biomed. Pharmacother. 58, 111-115.

Saccone, N. L., Culverhouse, R. C., Schwantes-An, T. H., Cannon, D. S., Chen, X., and Cichon, S. (2010). Giegling multiple independent loci at chromosome $15 \mathrm{q} 25.1$ affect smoking quantity: a meta-analysis and comparison with lung cancer and COPD. PLoS Genet. 6:ii:e1001053. doi:10.1371/journal.pgen.1001053

Sajja, R. K., Dwivedi, C., and Rahman, S. (2010). Nicotinic ligands modulate ethanol-induced dopamine function in mice. Pharmacology 86, 168-173.

Sajja, R. K., and Rahman, S. (2011). Lobeline and cytisine reduce voluntary ethanol drinking behavior in male C57BL/6J mice. Prog. Neuropsychopharmacol. Biol. Psychiatry $35,257-264$.

Sajja, R. K., and Rahman, S. (2012). Neuronal nicotinic receptor ligands modulate chronic nicotine-induced ethanol consumption in C57BL/6J mice. Pharmacol. Biochem. Behav. 102, 36-43.

Salamone, J. D., and Correa, M. (2012). The mysterious motivational functions of mesolimbic dopamine. $\mathrm{Neu}$ ron $76,470-485$.

Salas, R., Sturm, R., Boulter, J., and De Biasi, M. (2009). Nicotinic receptors in the habenulo-interpeduncular system are necessary for nicotine withdrawal in mice. J. Neurosci. 29, 3014-3018.

Salminen, O., Drapeau, J. A., McIntosh, J. M., Collins, A. C., Marks, M. J., and Grady, S. R. (2007). Pharmacology of alpha-conotoxin MII-sensitive subtypes of nicotinic acetylcholine receptors isolated by breeding of null mutant mice. Mol. Pharmacol. 71, 1563-1571.

Salminen, O., Murphy, K. L., McIntosh, J. M., Drago, J., Marks, M. J., Collins, A. C., et al. (2004). Subunit composition and pharmacology of two classes of striatal presynaptic nicotinic acetylcholine receptors mediating dopamine release in mice. Mol. Pharmacol. 65, 1526-1535.
Samson, H. H., Tolliver, G. A., Haraguchi, M., and Hodge, C. W. (1992). Alcohol self-administration: role of mesolimbic dopamine. Ann. N. Y. Acad. Sci. 654, 242-253.

Santos, N., Chatterjee, S., Henry, A., Holgate, J., and Bartlett, S. E. (2012). The alpha5 neuronal nicotinic acetylcholine receptor subunit plays an important role in the sedative effects of ethanol but does not modulate consumption in mice. Alcohol. Clin. Exp. Res. 37, 655-662.

Schlaepfer, I. R., Hoft, N. R., Collins, A. C., Corley, R. P., Hewitt, J. K., Hopfer, C. J., et al. (2008). The CHRNA5/A3/B4 gene cluster variability as an important determinant of early alcohol and tobacco initiation in young adults. Biol. Psychiatry 63, 1039-1046.

Schultz, W. (2004). Neural coding of basic reward terms of animal learning theory, game theory, microeconomics and behavioural ecology. Curr. Opin. Neurobiol. 14, 139-147.

Semba, K., and Fibiger, H. C. (1992). Afferent connections of the laterodorsal and the pedunculopontine tegmental nuclei in the rat: a retro- and antero-grade transport and immunohistochemical study. J. Comp. Neurol. 323, 387-410.

Sesack, S. R., and Pickel, V. M. (1992). Prefrontal cortical efferents in the rat synapse on unlabeled neuronal targets of catecholamine terminals in the nucleus accumbens septi and on dopamine neurons in the ventral tegmental area. J. Comp. Neurol. 320 145-160.

Shabat-Simon, M., Levy, D., Amir, A., Rehavi, M., and Zangen, A. (2008). Dissociation between rewarding and psychomotor effects of opiates: differential roles for glutamate receptors within anterior and posterior portions of the ventral tegmental area. J. Neurosci. 28, 8406-8416.

Sharpe, A. L., and Samson, H. H. (2002). Repeated nicotine injections decrease operant ethanol selfadministration. Alcohol 28, 1-7.

Sherva, R., Kranzler, H. R., Yu, Y., Logue, M. W., Poling, J., Arias, A. J., et al. (2010). Variation in nicotinic acetylcholine receptor genes is associated with multiple substance dependence phenotypes. Neuropsychopharmacology 35, 1921-1931.

Sine, S. M. (2002). The nicotinic receptor ligand binding domain. J. Neurobiol. 53, 431-446.

Smith, B. R., Horan, J. T., Gaskin, S., and Amit, Z. (1999). Exposure to nicotine enhances acquisition of ethanol drinking by laboratory rats in a limited access paradigm. Psychopharmacology (Berl.) 142, 408-412.

Soderpalm, B., Ericson, M., Olausson, P., Blomqvist, O., and Engel, J. A. (2000). Nicotinic mechanisms involved in the dopamine activating and reinforcing properties of ethanol. Behav. Brain Res. 113, 85-96.

Spanagel, R. (2009). Alcoholism: a systems approach from molecular physiology to addictive behavior. Physiol. Rev. 89, 649-705.

Steensland, P., Simms, J. A., Holgate, J., Richards, J. K., and Bartlett, S. E. (2007). Varenicline, an alpha4beta2 nicotinic acetylcholine receptor partial agonist, selectively decreases ethanol consumption and seeking. Proc. Natl. Acad. Sci. U.S.A. 104, 12518-12523.

Stephens, S. H., Hoft, N. R. I., Schlaepfer, R., Young, S. E., Corley, R. C., McQueen, M. B., et al. (2012). Externalizing behaviors are associated with SNPs in the CHRNA5/CHRNA3/CHRNB4 gene cluster. Behav. Genet. 42, 402-414.

Swanson, L. W. (1982). The projections of the ventral tegmental area and adjacent regions: a combined fluorescent retrograde tracer and immunofluorescence study in the rat. Brain Res. Bull. 9, 321-353.

Tapper, A. R., McKinney, S. L., Nashmi, R., Schwarz, J., Deshpande, P., Labarca, C., et al. (2004). Nicotine activation of alpha4* receptors: sufficient for reward, tolerance, and sensitization. Science 306, 1029-1032.

Theile, J. W., Morikawa, H., Gonzales, R. A., and Morrisett, R. A. (2011). GABAergic transmission modulates ethanol excitation of ventral tegmental area dopamine neurons. Neuroscience 172, 94-103.

Thorgeirsson, T. E., Gudbjartsson, D. F., Surakka, I., Vink, J. M., Amin, N., Geller, F., et al. (2010). Sequence variants at CHRNB3-CHRNA6 and CYP2A6 affect smoking behavior. Nat. Genet. 42, 448-453.

Tolu, S., Eddine, R., Marti, F., David, V., Graupner, M., Pons, S., et al. (2012). Co-activation of VTA DA and GABA neurons mediates nicotine reinforcement. Mol. Psychiatry $18,382-393$.

Tonstad, S., Tonnesen, P., Hajek, P. Williams, K. E., Billing, C. B., and Reeves, K. R. (2006). Effect of maintenance therapy with varenicline on smoking cessation: a randomized controlled trial. JAMA 296, 64-71. 
True, W. R., Xian, H., Scherrer, J. F., Madden, P. A., Bucholz, K. K., Heath, A. C., et al. (1999). Common genetic vulnerability for nicotine and alcohol dependence in men. Arch. Gen. Psychiatry 56, 655-661.

Tyndale, R. F. (2003). Genetics of alcohol and tobacco use in humans. Ann. Med. 35, 94-121.

Unwin, N. (2005). Refined structure of the nicotinic acetylcholine receptor at 4A resolution. J. Mol. Biol. 346, 967-989.

Volpicelli, J. R., Alterman, A. I., Hayashida, M., and O'Brien, C. P. (1992). Naltrexone in the treatment of alcohol dependence. Arch. Gen. Psychiatry 49, 876-880.

Wang, J. C., Grucza, R., Cruchaga, C., Hinrichs, A. L., Bertelsen, S., Budde, J. P., et al. (2009). Genetic variation in the CHRNA5 gene affects mRNA levels and is associated with risk for alcohol dependence. Mol. Psychiatry 14, 501-510.

Weiss, F., Lorang, M. T., Bloom, F. E., and Koob, G. F. (1993). Oral alcohol selfadministration stimulates dopamine release in the rat nucleus accumbens: genetic and motivational determinants. J. Pharmacol. Exp. Ther. 267, 250-258.

Wise, R. A., and Bozarth, M. A. (1987). A psychomotor stimulant theory of addiction. Psychol. Rev. 94, 469-492.

Wonnacott, S. (1997). Presynaptic nicotinic ACh receptors. Trends Neurosci. 20, 92-98.

World Health Organization. (2011). Department of Mental Health and Substance Abuse, Global Status Report on Alcohol 2011, World Health Organization, Department of Mental Health and Substance Abuse, Geneva.

Wouda, J. A., Riga, D., De Vries, W., Stegeman, M., van Mourik, Y., Schetters, D., et al. (2011). Varenicline attenuates cue-induced relapse to alcohol, but not nicotine seeking, while reducing inhibitory response control. Psychopharmacology (Berl.) 216, 267-277.

Wu, G., Tonner, P. H., and Miller, K. W. (1994). Ethanol stabilizes the open channel state of the Torpedo nicotinic acetylcholine receptor. Mol. Pharmacol. 45, 102-108.

Xiao, C., Shao, X. M., Olive, M. F., Griffin, W. C. III, Li, K. Y., Krnjevic, K., et al. (2009). Ethanol facilitates glutamatergic transmission to dopamine neurons in the ventral tegmental area. Neuropsychopharmacology 34, 307-318.

Xiao, C., and Ye, J. H. (2008). Ethanol dually modulates GABAergic synaptic transmission onto dopaminergic neurons in ventral tegmental area: role of mu-opioid receptors. Neuroscience 153, 240-248.

Yeomans, J. S., Mathur, A., and Tampakeras, M. (1993). Rewarding brain stimulation: role of tegmental cholinergic neurons that activate dopamine neurons. Behav. Neurosci. 107, 1077-1087.

York, J. L., and Hirsch, J. A. (1995) Drinking patterns and health status in smoking and nonsmoking alcoholics. Alcohol. Clin. Exp. Res. 19, 666-673.

Zhao-Shea, R., Liu, L., Soll, L. G. Improgo, M. R., Meyers, E. E., McIntosh, J. M., et al. (2011). Nicotine-mediated activation of dopaminergic neurons in distinct regions of the ventral tegmental area. Neuropsychopharmacology 36 1021-1032.

Zuo, Y., Nagata, K., Yeh, J. Z., and Narahashi, T. (2004). Single-channel analyses of ethanol modulation of neuronal nicotinic acetylcholine receptors. Alcohol. Clin. Exp. Res. 28, 688-696.

Zwart, R., and Vijverberg, H. P. (1998). Four pharmacologically distinct subtypes of alpha4beta2 nicotinic acetylcholine receptor expressed in Xenopus laevis oocytes. Mol. Pharmacol. 54, 1124-1131.

Conflict of Interest Statement: The authors declare that the research was conducted in the absence of any commercial or financial relationships that could be construed as a potential conflict of interest.

Received: 29 January 2013; accepted: 16 April 2013; published online: 30 April 2013.

Citation: Hendrickson LM, Guildford MJ and Tapper AR (2013) Neuronal nicotinic acetylcholine receptors: common molecular substrates of nicotine and alcohol dependence. Front. Psychiatry 4:29. doi: 10.3389/fpsyt.2013.00029

This article was submitted to Frontiers in Addictive Disorders and Behavioral Dyscontrol, a specialty of Frontiers in Psychiatry.

Copyright (c) 2013 Hendrickson, Guildford and Tapper. This is an openaccess article distributed under the terms of the Creative Commons Attribution License, which permits use, distribution and reproduction in other forums, provided the original authors and source are credited and subject to any copyright notices concerning any third-party graphics etc. 